University of Wollongong

Research Online

Faculty of Science, Medicine and Health -

Papers: part A

Faculty of Science, Medicine and Health

$1-1-2015$

\title{
Lithostratigraphic and sequence stratigraphic architecture of the Winduck Interval, central Darling Basin, Australia, based on integration of wireline logs, cores and cuttings data
}

\author{
M KH Khalifa \\ University of Zawia \\ Brian G. Jones \\ University of Wollongong, briangj@uow.edu.au \\ W M. Mahmud \\ University of Tripoli
}

Follow this and additional works at: https://ro.uow.edu.au/smhpapers

Part of the Medicine and Health Sciences Commons, and the Social and Behavioral Sciences

\section{Commons}

\section{Recommended Citation}

Khalifa, M KH; Jones, Brian G.; and Mahmud, W M., "Lithostratigraphic and sequence stratigraphic architecture of the Winduck Interval, central Darling Basin, Australia, based on integration of wireline logs, cores and cuttings data" (2015). Faculty of Science, Medicine and Health - Papers: part A. 3642. https://ro.uow.edu.au/smhpapers/3642 


\title{
Lithostratigraphic and sequence stratigraphic architecture of the Winduck Interval, central Darling Basin, Australia, based on integration of wireline logs, cores and cuttings data
}

\author{
Abstract \\ An integration of lithostratigraphy and general sedimentary facies character for non-marine rocks can be \\ a powerful tool in understanding the sequence stratigraphic architecture of the subsurface latest Silurian \\ to Early Devonian Winduck Interval in the Blantyre and western Neckarboo sub-basins, central Darling \\ Basin. This study integrates wireline logs (gamma ray and resistivity), cores and cuttings data to \\ determine the sequence stratigraphic subdivision of the study area. The lithostratigraphy of the Winduck \\ Interval could be subdivided into three units (A, B and $C$, in ascending order) in the four available wells \\ (Mount Emu 1, Kewell East 1, Booligal Creek 1 and Booligal Creek 2). Closer study of the sequence \\ stratigraphy in the approximately 850-m-thick Winduck Interval revealed ten parasequences (A-J) in \\ progradational to retrogradational parasequence sets and three main Winduck sequences, WKS1, WKS2 \\ and WKS3. Use of the suggested sequence stratigraphic model of the Winduck Interval has the potential \\ to refine existing lithostratigraphic schemes and, given the higher resolution and more detailed \\ correlation, may significantly improve subsurface stratigraphic reconstructions and aid in prediction of \\ hydrocarbon-bearing reservoirs. \\ Disciplines \\ Medicine and Health Sciences | Social and Behavioral Sciences \\ Publication Details \\ Khalifa, M. KH., Jones, B. G. \& Mahmud, W. M. (2016). Lithostratigraphic and sequence stratigraphic \\ architecture of the Winduck Interval, central Darling Basin, Australia, based on integration of wireline logs, \\ cores and cuttings data. International Journal of Earth Sciences, 105 (4), 1109-1126.
}


Lithostratigraphic and sequence stratigraphic architecture of Winduck Interval in the central part of the Darling Basin, Australia, based on integration

of wireline logs, cores and cuttings data

\footnotetext{
Mohamed Kh. Khalifa ${ }^{\mathrm{a}, \mathrm{b}}$, Brian G. Jones ${ }^{\mathrm{c}}$ and Walid Mohamed Mahmud ${ }^{\mathrm{d}}$

a Department of Geology, Faculty of Science in the University of Malaya, Malaysia

${ }^{\mathrm{b}}$ Department of Geology, Faculty of Science, University of Zawia, Libya

${ }^{c}$ School of Earth and Environmental Sciences, University of Wollongong, Australia

${ }^{\mathrm{d}}$ Department of Petroleum Engineering, University of Tripoli, Libya
}

\section{ABSTRACT}

Email address: mohamed20au@yahoo.com / mohamed_kh@um.edu.my

An integration of lithostratigraphy and general sedimentary facies character for nonmarine rocks can be a powerful tool in understanding the sequence stratigraphic architecture of the subsurface latest Silurian to Early Devonian Winduck Interval in the Blantyre and western Neckarboo Sub-basins, central Darling Basin. The study integrates wireline-logs, cores and cuttings data to determine the sequence stratigraphic subdivision of the study area. The study involved two main categories. The first category, through integrating wireline logs (gamma ray and resistivity patterns) characteristics and core and cutting descriptions data, we found that the lithostratigraphic unit correlations (it is subdivided into three units A, B and C, in ascending order) is proposed for the Winduck Interval on the basis of its distinctive lithologic character as interpreted from four wells (Mount Emu1, Kewell East 1, Booligal Creek 1 and Booligal Creek 2). Secondly, we interpreted sequence stratigraphy in the approximately $850 \mathrm{~m}$ thick the latest Silurian to Early Devonian Winduck Interval, a more detailed sequence stratigraphic subdivision is suggested within the ten parasequences are named A, B, C, D, E, F, G, H, I and J in progradational to retrogradational parasequence sets and three main Winduck sequences, WKS1, WKS2 and WKS3 are informally defined within the latest Silurian to lower Devonian succession. Use of the suggested sequence stratigraphic model of the Winduck Interval has the potential to refine existing lithostratigraphic schemes and, given the higher resolution and more detailed correlation, may significantly improve subsurface stratigraphic reconstructions and aid in prediction of potentially hydrocarbon-bearing reservoirs.

KEY WORDS: Blantyre Sub-basin, western Neckarboo Sub-basin, latest Silurian to Early Devonian, Winduck Interval, wireline log data, core descriptions, lithostratigraphy, sequence stratigraphy, parasequences.

\section{Introduction}

The purpose of the study was to establish a thorough understanding of the major lithostratigraphic unit distribution of sequence stratigraphic architecture within the latest Silurian to Early Devonian Winduck Interval section of the Blantyre and western Neckarboo Sub-basins, central Darling Basin and identify prospective areas for hydrocarbon exploration (Fig 1). In this paper, we address two important areas of studylithostratigraphy and sequence stratigraphy. This paper presents a re-evaluation of the lithostratigraphy in part of the study area from four wells (Kewell East 1, Mount Emu 1, Booligal Creek 1 and Booligal Creek 2; Fig. 1C). The Winduck Interval was not penetrated in other wells (Blantyre 1 and Snake Flat 1) in this part of the basin. This article discuses the application of these analytical techniques to subsurface geology, highlighting some of the problems and potential benefits, using a case study from the 
Darling Basin. Regionally correlatable non-marine sequences are documented and integrated with sedimentologically constrained data into lithostratigraphic and sequence stratigraphic architecture. The latest Silurian to Early Devonian Winduck Interval has long been used to defined sedimentary facies in terms of lithostratigraphic analysis related to sequence stratigraphic analysis in other basins worldwide (e.g. Nadon et al., 84; Pedersen, 2003; Bouougria \& Saquaqueb, 2004; Duarte, 2007; Aleali et al. 2013; Meor et al., 2013).

A number of the published papers discuss stratigraphic correlations, both regional and local, but few deal with regional latest Silurian to Early Devonian sequences based on correlations. Among the earliest publications are those by Neef and Bottrill (1991), Alder et al. (1998), Bembrick (1997a, b), Neef (2004, 2005) and Cooney \& Mantaring (2007). The integration of sedimentology and stratigraphy has recently focussed on in sequence stratigraphic papers by Willcox et al. (2003), Khalifa (2005, 2006a, b), Khalifa \& Ward (2009) and Khalifa \& Alta'ee (2011).

In this way, Khalifa, Jones and Hlal (pers. comm.) have proposed twenty nine subsurface sedimentary facies, which were grouped into five facies associations a clearly defined by wireline-log signatures integrated with lithological sample logs (cores and cuttings) in the latest Silurian to Early Devonian Winduck Interval in the Blantyre and western Neckarboo Sub-basins, which are summarised in Table 1 (see also the detailed sedimentary logs of the latest Silurian to Early Devonian Winduck Interval in Figs. 5, 7 and 8: $c f$. Khalifa, Jones and Hlal, pers. comm.). Sequence stratigraphic-lithostratigraphic models commonly used to predict facies reservoir distributions represent frozen time windows, whereas in reality depositional systems and stacking patterns of facies associations are dynamic. The synergy of lithostratigraphic and sequence stratigraphic approaches can provide a powerful and reliable tool based on the integration of all available data. The sequence stratigraphic terminology of Van Wagoner et al. (1998, 1990) is used throughout.

The objectives of this study have been: (1) to determine the extent and geometry of each of the proposed lithostratigraphic units within the Winduck Interval; (2) to delineate sequence stratigraphic boundaries; (3) to determine detailed sedimentary geometries within the parasequences, as well as the variability of parasequence boundaries within the Winduck Interval; and (4) to determine the processes responsible for the development of sequences in Blantyre Sub-basin (Booligal Creek 1, 2 and Mount Emu 1 wells) and western Neckarboo Sub-basin (Kewell East 1 well). The present synthesis allows us to offer a new interpretation of the lithostratigraphy of a sequence correlated with the latest Silurian to Early Devonian Winduck Interval of the Blantyre and western Neckarboo Subbasins. We also describe the sequence stratigraphic architecture of fill in the Blantyre Subbasin and, hence, its petroleum potential.

\section{Geologic background}

\subsection{Stratigraphic subdivision of the Winduck Interval}

The stratigraphy of the Darling Basin has been summarised by Bembrick (1997a, b), Alder et al. (1998) and other authors and is adopted herein. Bembrick noted that prior literature contained a 'terminological maze' of often-conflicting strato-tectonic terms to describe the various lithofacies in the basin. Consequently, in an effort to standardise the nomenclature, adopted an informal, non-genetic, 'working stratigraphy' intended as a framework for future refinement and adaptation. For the Siluro-Devonian section, Bembrick proposed the following lithostratigraphic terms to name the intervals (in order of decreasing age) - the Winduck Interval, the Snake Cave Interval and the Ravendale 
Interval. These units are bounded by major sequence boundaries, marked by significant breaks in sedimentation that are accompanied by varying amounts of structural movement and erosion. These sequence boundaries also correspond with the major seismic events noted by Evans (1977; Table 1, p. 44) and are equivalent to the major tectonic events described by other authors. They are - the late Silurian Bowning Orogeny, probably related to Horizon A, the early Devonian Bindian Orogeny, probably related to Horizon B, the late Mid-Devonian Tabberabberan Orogeny, probably related to Horizon $\mathrm{C}$ and the Carboniferous Kanimblan Orogeny, probably representing Horizon D (cf. Khalifa 2009: Table 2). The purpose of this study was to evaluate the critical elements of the lithostratigraphy and sedimentology for the thick sediment packages in the area, focusing on the latest Silurian to Early Devonian Winduck Interval.

However, the basic and most widely accepted published stratigraphic framework for the Darling Basin, western New South Wales, has been derived from Evans (1977), Byrnes (1985), Glen (1979, 1982a, b, 1986), Neef et al. (1989), Neef \& Bottrill (1991), Bembrick (1997a, b), Alder et al. (1998), Cooney \& Mantaring (2007), Khalifa (2005, 2006a, 2007, 2009, 2010) and Khalifa \& Ward (2009). Wide varieties of lithostratigraphic unit names have been used to describe distinct sedimentary units, many of which are laterally discontinuous. A simplified lithostratigraphic units scheme (Fig. 2A) currently applied to the Winduck Interval is based on the work of Andrews (1913), Rayner (1962), Glen (1982a, b), Neef et al. (1989), Neef \& Bottrill (1991), Neef et al. (1996), Vickery et al. (1989) and Bembrick (1997a, b).

The Winduck Interval has been identified in many wells throughout the Darling Basin. Fig. 2B shows the large-scale facies sequence framework for the Winduck Interval that ranges from alluvial/fluvial in the west to fluvio-deltaic and shallow-shelf in the east where it generally contains an abundance of shelly macrofauna. It is probable that the shallow-shelf conditions were present as far west as the eastern margins of the Lake Wintlow High and Wonominta Block. A general provenance to the west and southwest is indicated, with a gradual eastward progradation of the younger (fluvial and fluvio-deltaic) units over the shelf. This interval therefore represents a broad regression at the closing stages of deeper water sedimentation in the Cobar Basin, the Nelyambo Trough and probably other depocenters to the west. It is in fact coeval with the upper Amphitheatre Group deposition in the Cobar area (Glen, 1986).

In summary, the stratigraphy and sedimentology of the latest Silurian to Early Devonian Winduck Interval and equivalents is now recognised across the Darling Basin, both in outcrop and in the subsurface. These strata are represented by the Mt Daubeny Formation in the western part of the basin, the Winduck Group in the central and eastern parts, and the upper Amphitheatre Group in the eastern part of the basin (Fig. 2A and B). In the subsurface, the rocks stratigraphically equivalent to the Winduck Group are referred to as the Winduck Interval, following the nomenclature of Bembrick (1997a, b).

\subsection{Distribution and stratigraphic sequence relationships}

In a classical study of the area, Khalifa (2005, 2009) and Khalifa \& Ward (2009) have shown that the Winduck Interval can be recognised within latest Silurian to Early Devonian succession. This interpretation was based on the positions of the stratigraphic boundaries in the available exploration wells based on the wireline logs, core and cutting descriptions and on interpretation of seismic lines (see Khalifa \& Ward 2009, 2010). Further stratigraphic subdivision of the Winduck Interval in the wells in the Blantyre and western Neckarboo Sub-basins was difficult due to the limited number of seismic markers and the limited availability of supplementary biostratigraphic data. This interpretation was confirmed in wells that encountered the Winduck/Snake Cave boundary, such as Mount 
Emu 1 well (Khalifa 2005, 2009; Khalifa \& Ward 2009), Kewell East 1 well (Clark et al. 2001; Khalifa \& Ward 2009), and the Winduck Interval/Tertiary sediment boundary in Booligal Creek 1 and Booligal Creek 2 wells (Khalifa 2005, 2009; Khalifa \& Ward 2009).

Khalifa (2005, 2009, 2010) and Khalifa \& Ward (2009) defined the position of the lithostratigraphic boundary between the top of the Winduck and the bottom of the Snake Cave Intervals as seismic horizon-2 and it can be traced on seismic lines through Kewell East 1 and Mount Emu 1 wells. The boundary is marked in Mount Emu 1 well by an abrupt lithologic change and a sharp decrease in the gamma-ray log value at a depth of 612 m (cf. Khalifa \& Ward, 2009: Fig. 5). In the fully cored Kewell East 1 well, the upper part of the Winduck Interval consists of interbedded sandstone and shale, whereas the lower part of the Snake Cave Interval is relatively pure sandstone. The contrast is also, seen in the gamma-ray log, which has relatively high values in the upper Winduck Interval, but drops sharply above $378 \mathrm{~m}$ to lower values in the overlying lower Snake Cave Interval (cf. Khalifa \& Ward, 2009: Fig. 5).

Recent work by Khalifa (2005) and Khalifa \& Ward (2009) re-evaluated the position of the Winduck/Tertiary boundary in the available core samples for Booligal Creek 1 and Booligal Creek 2 wells. However, the Tertiary sediments in this area consist of interbedded sandstone and siltstone (Jessop and Cowan-Lunn, 1996a, b), which makes separating the Winduck and Tertiary sediments difficult in the wells based on lithology alone. Evidence from interpretation of seismic line SS134>HD-129 indicates an erosional unconformity between the top of the Winduck Interval and the base of the Tertiary sediments (cf. Khalifa \& Ward 2009: Fig. 12).

\section{Database and methods}

\subsection{Database}

The database for this high-resolution study including well completion reports, wireline logs, core and cutting data from four wells, which were used to develop a lithostratigraphic and sequence stratigraphic framework for the latest Silurian to Early Devonian Winduck Interval deposits of the Blantyre and western Neckarboo Sub-basins (Table 2).

The comparison of cored sequences to accompanying wireline-log responses facilitated correlations between lithostratigraphic units, sedimentary facies and sequence stratigraphic units between uncored intervals. The gamma ray and resistivity wireline log characteristics and other subsurface data from Kewell East 1 and Mount Emu 1 were used for interpretation. Three fully cored wells (Kewell East 1, Booligal Creek 1 and Booligal Creek 2) in the Blantyre and western Neckarboo Sub-basins provided detailed lithologic data, and good well control allowed high resolution lateral sedimentary facies correlation. The small amount of biostratigraphic data acquired from Kewell East 1 and Mount Emu 1 wells provided important corroboration of sequence stratigraphic interpretations and is discussed in more detail below.

\subsection{Methods}

The methodology employed for the lithostratigraphic and sequence stratigraphic analysis and correlation involved the following two aspects:

Firstly, all Winduck Interval core and cutting samples from the Blantyre and western Neckarboo Sub-basins together with selected nearby wells were described and interpreted in terms of lithostratigraphic units from well logs alone. Gamma ray and resistivity logs from two wells (Kewell East 1 and Mount Emu 1) were correlated to 
establish the lithostratigraphic units and the relative sandstone vs shale content. Also, matching of lithologic information observed in fully cored samples (description from Kewell East 1, Booligal Creek 1 and Booligal Creek 2 wells) to specific log responses allowed recognition of a range of well-log signatures characteristic of the Winduck Interval and helped to provide the necessary lithostratigraphic control. The distribution patterns of these units were determined from well log correlations within the Winduck Interval in the Blantyre and western Neckarboo Sub-basins. Finally, we present a regional sequence stratigraphical framework for the Winduck Interval was developed from facies associations, derived from cores, cuttings and wireline logs using the techniques for sequence stratigraphic studies outlined by Van Wagoner et al. $(1988,1990)$ and Galloway (1989). The well data were used to correlate specific sequence boundaries between boreholes (e.g. Kewell East 1 and Mount Emu 1, Booligal Creek 1 and Booligal Creek 2) and to define the parasequence geometry. Integration of different parasequence stacking cycles identified from well-log section, allowed development of a sequence stratigraphiclithostratigraphic model of the Winduck Interval within the Blantyre and western Neckarboo Sub-basins.

\section{Results}

4.1. Use of wireline log signatures to interpret subsurface lithostratigraphic units in the Winduck Interval

The lithostratigraphic correlation used in this study is based on wireline-logs and lithological data from four wells. Most of the lithostratigraphic units identified from cores and cuttings have characteristic wireline-log responses. In wells, thickness of strata in the sandstone, siltstone, shale, shaly siltstone and silty shale range from less than one metre to several hundred metres.

The lithostratigraphic correlation describes unit geometries within the Winduck Interval. Main lithostratigraphic unit studies have focused on Kewell East 1 well (Fig. 3), which is regarded as the stratigraphic reference section for the Winduck Interval because of its extensive core coverage (intersected from $378 \mathrm{~m}$ to the termination depth of $1224 \mathrm{~m}$ ) and the relatively complete stratigraphy preserved in this location. The complex stratigraphy in the Blantyre and western Neckarboo Sub-basins has been illustrated in previous publications (Bembrick 1997a, b; Alder et al. 1998; Khalifa; 2005, 2006a, b, 2010; Cooney \& Mantaring 2007; Khalifa \& Ward 2009; Khalifa \& Alta'ee 2011).

The relationship between wireline log (gamma ray and resistivity) responses and lithostratigraphic units is illustrated by Kewell East 1 and Mount Emu 1 wells (Fig. 3). In the wells, characteristic log segments equate with the lithostratigraphic units recognized from core lithologic logs in Booligal Creek 1 and Booligal Creek 2 wells (Fig. 3). The various distributions and thicknesses of lithostratigraphic units are shown in Table 3.

The latest Silurian to Early Devonian Winduck Interval deposits in the Blantyre and western Neckarboo Sub-basins comprise three lithostratigraphic units, bounded by scudded changes identified from wireline log characteristics and lithologic core descriptions. Consequently, the redefined units are not significantly different from the original units, but are now defined at other wells and the definitions have been adjusted to provide a firmer sequence stratigraphical framework for wireline log stratigraphic correlation. Each lithostratigraphic unit is briefly described below in ascending order of occurrence. 


\subsubsection{Lithostratigraphic unit A correlation}

The top of lithostratigraphic unit A is seen most clearly in wireline logs and core lithologies (Fig. 3), which generally exhibit a sharp based high gamma-ray pattern and relatively low resistivity values. Two log markers can be identified in wells, one at about $783 \mathrm{~m}$ in Kewell East 1 well shows the high gamma-ray-log corresponds to relatively high shale units, and the other at $1024 \mathrm{~m}$ in Mount Emu 1 well where the boundary is marked by a high gamma-ray value. Correlation of similar gamma-ray and resistivity curve patterns, supported by the core and cuttings from Kewell East 1 and Mount Emu 1 wells shows a bow-shaped log motif that is the pick for the top of lithostratigraphic unit A (Fig. 3 ). The top of the unit in Booligal Creek 2 well is marked by a change in the core lithologic response at a depth of $500 \mathrm{~m}$ and it occurs at an estimated depth of $260 \mathrm{~m}$ in Booligal Creek 1 well (Fig. 3).

Interpretation of the correlation of the wireline log and core lithologies in the course of the present study has shown that the base of lithostratigraphic unit A is not completely presented in Mount Emu 1, Kewell East 1 and Booligal Creek 1 and 2 wells (see Fig. 3). The lower part of lithostratigraphic unit A is mainly composed of sandstone and siltstone with intercalations of shale and few shaly siltstone beds that are variable in thickness (cf. Bembrick, 1997b; Khalifa, 2005; Khalifa \& Ward, 2009).

\subsubsection{Lithostratigraphic unit B correlation}

Lithostratigraphic unit B gradationally overlies lithostratigraphic unit $A$ in the Kewell East 1, Mount Emu 1 and Booligal Creek 2 wells, whereas it is absent from Booligal Creek 1 well (Table 3). Fig. 3 shows the well-log response through the top of unit B as an abrupt lithological change, but it is represented by strong, sharp, low gamma ray values in Mount Emu 1 well (around $797 \mathrm{~m}$ ) and a log segment with relatively low gamma-ray values in Kewell East 1 well (around $577 \mathrm{~m}$ ). In Booligal Creek 2 well on the northwestern flank of the Blantyre Sub-basin the top of lithostratigraphic unit B is lithologically similar to the unit in the Kewell East 1 and Mount Emu 1 wells. The boundary between the top of unit B and the Tertiary sediments was intersected at a depth of 238 m in Booligal Creek 2 well (cf. Khalifa 2005; Khalifa \& Ward 2009: Fig. 12).

The lithologic features in unit B generally indicate the presence of interbedded sandstone and siltstone grading upward into silty shale. Thick sandstone beds separated by shale may occur repeatedly; however, the presence of interbedded, poorly developed sandstone in the lower unit implies a gradational transition into the siltstone and silty shale with minor shaly siltstone (Fig. 3).

\subsubsection{Lithostratigraphic unit $C$ correlation}

The top of lithostratigraphic unit $C$ generally exhibits a sharp top with a high gamma-ray pattern and relatively low resistivity values (Fig. 3). Two or three sandstone beds separated by thin shale beds occur in unit C; these beds are unconformably overlain by Tertiary sediments consisting of sandstone with thin siltstone (cf. Khalifa, 2005; Khalifa \& Ward, 2009: Figs. 8, 12).

Correlation of the wireline log (gamma ray and resistivity) responses from Kewell East 1 well to Mount Emu 1 well shows the top of lithostratigraphic unit C. The boundary shows a clear lithological change on the gamma-ray logs in Mount Emu 1 well at $612 \mathrm{~m}$ and Kewell East 1 well at $378 \mathrm{~m}$ (Fig. 3). In lithostratigraphic unit C the sandstone is medium- to very fine-grained but dominantly fine- to very fine-grained with associated siltstone, shaley siltstone and shale interbeds that exhibit well-developed fining-upward trends (Fig. 3). Lithostratigraphic unit C reaches a maximum thickness of $199 \mathrm{~m}$ in Kewell East 1 well while it is $185 \mathrm{~m}$ in Mount Emu 1 well. It is absent from Booligal Creek 1 and 2 wells (Fig. 3). 


\subsection{Sequence stratigraphical framework}

Standard methods of sequence-stratigraphic mapping (Van Wagoner et al. 1988, 1990; Posamentier \& Vail 1988; Galloway 1989) were used to identify parasequences and sequences on wireline logs and cores and to build up the large-scale sequence stratigraphical framework of the Winduck Interval in the Blantyre and western Neckarboo Sub-basins.

This work has identified probable third-order and higher frequency sequences and their associated systems tracts within the Winduck Interval (Figs. 4-6A, B). However, three types of key stratigraphic surface have been identified in this study area using the sequence stratigraphical framework previously developed (Fig. 7). These have been used in a deterministic manner with regard to Winduck Interval correlation, and can be listed as follows: (1) sequence boundary; (2) parasequence boundary (minor flooding surface) and (3) maximum flooding surface. Three sequences and ten parasequences have been identified in the Winduck Interval and are characterized as distributary channel sandstone complex, distributary mouth bar, tidal channel sand, proximal delta front associated with mouth bars complex and distal delta front to prodelta sediments (Table 1).

The applicability of wireline-log signatures for defining the parasequences and sequences in the Winduck Interval shows three major sequences, the Winduck sequence 1 (WKS1), Winduck sequence 2 (WKS2) and Winduck sequence 3 (WKS3). We show that internally the sequences contain at least ten parasequences bounded by regionally mappable minor flooding surfaces (FS1-FS10). From oldest to youngest, the parasequences are named A, B, C, D, E, F, G, H, I, J and K (Fig. 7). These parasequences form progradational and retrogradational parasequence sets bounded by maximum flooding surfaces (MFS), as discussed in the next section.

\subsubsection{Definition of Winduck sequence 1 (WKS1)}

The sequence boundary (WKSB1) at the base of Winduck sequence 1 (WKS1) is picked near the bottom of the Winduck Interval at an erosion surface generally containing intermixed lithologies, claystone, siltstone and sandstone associated traces of paleosols (cf. Clark et al. 2001). The sequence boundary could be evidence that instead of an erosion surface, this contact is actually a sequence boundary, yet such evidence is not present in any of the other well sections. Although the sequence boundary of Winduck sequence 1 (WKS1) is represented by a marked increase in gamma-ray values and shift in resistivity, corresponding to incoming sand in the lithology log within Kewell East 1and Mount Emu 1 wells (Figs. 4, 5), which generally display a sharp based high gamma-ray pattern and relatively low resistivity values.

Four informal "major parasequences" are identified (Figs. 4-6A, B). The boundaries of these parasequences are identified on well logs are very import for studies. The entire study area, and they are interpreted to reflect major key stratigraphic surface in the well development.

4.2.1.1. Parasequence A. The parasequence $\mathrm{A}$ is the oldest parasequence in the Winduck sequence 1 (WKS1) in the study area. The flooding surface is labelled FS1, and observed in low gamma ray values correlative with grain size increases upward from sandstone beds below the boundary to shale above (Figs. 4 and 5). Evidence for a sandstone-dominated unit with interbedded siltstones ranging from 20 to 35\%, but less in the shaly beds in the western Neckarboo Sub-basin (parasequence A) is seen in Kewell East 1 well (Fig. 4), where an average about 8-10 $\mathrm{m}$ thick sandstone dominated unit has been interpreted. In Kewell East 1 and Mount Emu l well, gamma ray log deflections of parasequence A are similar. No wireline log interpretation exists for parasequence A, so lithologic log is 
interpreted from core samples in the Booligal Creek 2 well, on the northwestern flank of the Blantyre Sub-basin, although the well shows similarity to the upper part of parasequence A appear in the Kewell East 1 and Mount Emu 1 wells.

4.2.1.2. Parasequences $B$. Parasequence $B$ consists of the lower part of the Winduck sequence 1 , where it is topped by a flooding surface (FS2) which forms the boundary to the overlying parasequence $C$ (Figs. 4-6A, B). Interpreted of the parasequence identified gamma ray log patterns of blocky sandstones generally indicate the presence of sandstone bedsets and beds thicken upward with grain size increases upward (cf. Emery \& Myers, 1996 and Rider, 2002). However, the parasequence boundary (FS2) is marked by an abrupt change in lithology from sandstone below the boundary to shale above the boundary.

Parasequence B averages $80 \mathrm{~m}$ thick and contains an average of 60 to $70 \%$ sandstone. This parasequence is present by Kewell East 1, Mount Emu 1 and Booligal Creek 2 wells but is not present in the Booligal Creek 1 well.

4.2.1.3. Parasequence $C$. Parasequence $\mathrm{C}$ consists of the middle part of the Winduck sequence 1 , but parasequence $C$ has also been observed in the lower part of Winduck sequence 1 (WKS1), at the Booligal Creek 1 well (Fig. 6A), where it has a wide distribution in the study area. Parasequence $\mathrm{C}$ includes upward-coarsening to blocky (progradational unit), low gamma ray sandstones ranging from 10 to $20 \mathrm{~m}$ thick. Parasequence boundary (FS3) is marked by an abrupt change in lithology from sandstone below the boundary to shale or shaly siltstone above the boundary as an indicator of a marine flooding surface representing the upper surface of a parasequence C.

Overall, this parasequence averages $30 \mathrm{~m}$ thick and has average sandstone content of $50-60 \%$. Interbedded siltstones are $4-10 \mathrm{~m}$ thick, with an average $10 \%$ thin-bedded shale and shaly siltstone (see Booligal Creek 1, 2 wells: Fig. 6A, B).

4.2.1.4. Parasequence D. Observations of parasequence $\mathrm{D}$ are based entirely on subsurface data in the study area. In core lithology and wireline-log such as gamma ray and resistivity characters the unit appears similar to the previously described parasequences, showing a progradational set of stacked upward coarsening units within Winduck sequence 1 (Figs. 4-6A, B). Interpreting parasequence D from wireline-log shows that low gamma ray log and high resistivity log deflections indicate a boundary (FS4) marked by an abrupt change in lithology from sandstone below the boundary to siltstone or shaly siltstone above the boundary. Evidence for a well-log signature of the parasequence boundary as an indicator of a flooding surface representing the upper surface of a parasequence $\mathrm{D}$ can be observed in Figs. 4 and 5, and as suggested by core lithology in Booligal Creek 2 well (Fig. 6B).

Within a succession, the boundary of parasequence $D$ is similar to the sequence boundary (WKSB2) at the base of Winduck sequence 2 (WKS2), and flooding surface at the top, possibly with a parasequence boundary (FS4) within the upper surface of the parasequence D; labelled WKSB2/TS/FS4 (Figs. 4-6B).

Parasequence $\mathrm{D}$ is composed of sandstone beds as much as $10 \mathrm{~m}$ thick and interbedded siltstone beds 2-6 m thick with averages 10\% thin-bedded shale and shaly siltstone (see Kewell East 1 and Mount Emu 1 wells: Figs. 4, 5). Therefore, low gamma ray log and high resistivity log patterns are common for this parasequence that averages just over $100 \mathrm{~m}$ in thickness and has an average sandstone content of $20-30 \%$. The maximum known thickness of parasequence D (115 m) has been recorded in Kewell East 1 well and the minimum thickness (65 m) in Mount Emu 1 well. 


\subsubsection{Definition of Winduck sequence 2 (WKS2)}

The sequence boundary at the base of Winduck sequence 2 (WKS2) is locally an erosional surface on the underlying flooding surface on parasequence $\mathrm{D}$, and probably formed at the end of the highstand systems tract (HTS). It is bounded as interpreted of log trends in Kewell East 1 and Mount Emu 1 wells control to confirm sequence boundary (WKSB2), the sequence boundary coincides with parasequence boundary (FS4). However, the sequence boundary has a sharp base with a blocky wireline-log pattern (i.e., gamma-ray or resistivity curves) (Figs. 4 and 5). Five parasequences have been recognized and they are described and interpreted below.

4.2.2.1. Parasequence E. Parasequence E (predominantly a fining-upward pattern) in the lower part of Winduck sequence 2 (WKS2) is associated with an identified maximum flooding surface (MFS). Wells Kewell East and Mount Emu show the high gamma-raylog response to relatively high shale units within part of the maximum flooding surface (MFS) (cf. Emery \& Myers 1996; Rider 2002 and Slatt 2006).

Figs. 4, 5 and 6B shows the flooding surface at the top, possibly with a parasequence boundary (FS5) contained by the upper surface of the parasequence E. Also, parasequence boundary (FS5) coincides with a maximum flooding surface (MFS). Wireline-logs low gamma ray and high resistivity deflections show that the parasequence boundary (FS5) marks a locally sharp lithologic change from sandstone below the boundary to siltstone above the boundary. Furthermore, Kewell 1 and Mount Emu 1 confirm the location of the parasequence boundary (FS5) in the study area.

4.2.2.2. Parasequence $F$. Parasequence $F$ is predominantly a fining-upward pattern in the lower part of the Winduck sequence 2 (WKS2). The wireline-log shows a low gamma ray log and high resistivity log deflection shows the parasequence boundary (FS6) marks a local sharp change in lithology from sandstone below the boundary to siltstone above the boundary. Furthermore, Kewell East 1 and Mount Emu 1 wells (Figs. 5, 6) confirm the parasequence boundary (FS6) interpretation in the study area.

4.2.2.3. Parasequence G. Parasequence G consists of the lower part of the Winduck sequence 2, where it overlies parasequence F. Three well sections have been measured in this study area (see location of well section in Fig. 1). In the western Neckarboo Sub-basin at Kewell East section, parasequence $G$ on the log is marked by an upward increase in gamma-ray response, indicating an upward-fining parasequence and sharp parasequence boundary (FS7) as an indicator of a flooding surface and represents the base of the upper surface of parasequence G. Most of the parasequence boundary (FS7) is sharp, as indicated by wireline-log characteristics in Fig. 5 (see in Mount Emu 1) and as suggested by core lithology in Fig. 6B (see in Booligal Creek 2). The parasequence boundary (FS7) is shown by change in lithology from shale below the boundary to sandstone sometime siltstone above the boundary within three well sections.

Parasequence $G$ is made up of facies association (C) and facies association (D), so lithologic log is interpreted from core samples and wireline-logs (gamma-ray and resistivity $\log$ ) showing alternating siltstone, silty shale and sandstone with interbedded shale beds. Figs. 4, 5 and $6 \mathrm{~B}$ are well sections showing the distribution of strata of parasequence G, in the Mount Emu 1, Booligal Creek 2 and Kewell East 1 wells. It has an estimated thickness in this area of approximately $74 \mathrm{~m}$. Nevertheless, it is absent in the Booligal Creek 1, on the northwestern flank of the Blantyre Sub-basin.

4.2.2.4. Parasequence $H$. The sharp parasequence boundary (FS8) at the top of parasequence $\mathrm{H}$. In Mount Emu well, the boundary occurs within a marine flooding 
surface representing the upper surface of parasequence H. It is approximately 4-8 $\mathrm{m}$ above the parasequence boundary and is marked by a strong gamma-ray spike at the turnaround between upward-increasing to upward-decreasing gamma-ray values (Fig. 4). However, using both core lithologic logs and gamma-ray logs, it is difficult to pick an actual surface for the parasequence boundary (FS8) at the top of parasequence $\mathrm{H}$ (see in well, Kewell East 1 and Booligal Creek 2: Figs. 4, 6B).

Parasequence $\mathrm{H}$ is characterized by facies Association (D), suggesting deposition in a proximal delta front associated with mouth bars complex setting occurs in well sections in the Kewell East and Mount Emu, at the same time as a change of facies in the Booligal Creek 2 well, on the northwestern flank of the Blantyre Sub-basin, recognition of sediments deposited under tidal-channel sand facies association (C) (cf. Selley 1985; Reineck \& Singh 1980 and Reading 1986).

The subsurface distribution of parasequence $\mathrm{H}(\mathrm{PSH})$ is based on thickness trends and the parasequence reaches a maximum thickness of about $90 \mathrm{~m}$ in the Mount Emu 1 and a minimum thickness $(50 \mathrm{~m})$ in the Booligal Creek 2 well, and is absent in the Booligal Creek 1 well.

4.2.2.4. Parasequence I. Parasequence I consists of the middle part of the Winduck sequence 2 (WKS2) at the Kewell East 1 and Mount Emu 1 wells (Figs. 4, 5), but parasequence I has been observed in the upper part of the Winduck sequence 2 (WKS2), in the Booligal Creek 2 well (Fig. 6B). Within parasequence I, the flooding surface forming the upper boundary of this lowstand unit is correlative with a transgressive lag of fine-grained sandstone and silty shale overlying a transgressively reworked parasequence boundary (FS9). Correlation of similar gamma-ray curve patterns from Kewell East 1 to Mount Emu 1 wells shows a bow-shaped gamma-ray log motif that is the pick an actual surface for the parasequence boundary (FS9), and can display a more irregular wirelinelog pattern. Therefore, when parasequence I is interpreted from cores change in lithology from sandstone below the parasequence boundary (FS9) to silty shale or shaly siltstone above the parasequence boundary (FS9), although suspicious observation may reveal subtle evidence of flooding surface marking the parasequence boundary (see in well, Booligal Creek 2: Fig. 6B).

The correlation of parasequence I in the subsurface is based on thickness trends. Parasequence I attains a maximum thickness of more than $50 \mathrm{~m}$ in Mount Emu 1 well (Fig. 5), and it has been recorded in Booligal Creek 2 (42 m). It has a minimum thickness (35m) in well, Kewell East 1 (Fig. 4), but is absent in the Booligal Creek 1 well.

\subsubsection{Definition of Winduck sequence 3 (WKS3)}

The sequence boundary (WKSB3), according to wireline logs, is interpreted to be an upward-coarsening high-frequency sequence at the base of Winduck sequence 3 (WKS3) in Kewell East 1 and Mount Emu 1 wells where it is composed of at least two parasequences.

4.2.3.1. Parasequence J. Mapping of parasequence I in the subsurface is based on thickness trends and the thickness ranges from the Mount Emu 1 well $(74 \mathrm{~m})$ to the Kewell East 1 well $(123 \mathrm{~m})$ and the minimum thickness $(50 \mathrm{~m})$ in the Booligal Creek 2 well, but is absent in the Booligal Creek 1 well (Fig. 6A).

Parasequence $\mathrm{J}$ consists of the lower part of the Winduck sequence 3 (WKS3), where it overlies parasequence K at the Kewell East 1 and Mount Emu 1 wells (Figs. 4-6), but mapping has shown parasequence $\mathrm{J}$ in the uppermost part of the Winduck sequence 3 (WKS3), in Booligal Creek 2 well (Fig. 6B). 
The wireline-log response shows the parasequence boundary (FS10) at the top of parasequence J, throughout Kewell East 1 and Mount Emu 1 wells. Wireline logs display an upward-fining pattern that reverses below the boundary to an upward-coarsening pattern at distinct low gamma ray and high resistivity values (Figs. 4, 5). In wireline logs, the parasequence boundary displays a sharp change in lithology from shale below the boundary to fine- to medium-grained sandstone above the boundary within two well sections. Furthermore, within a succession, the boundary of parasequence $\mathrm{J}$ is similar to that at the base of Tertiary sediments (angular unconformity) as defined by Khalifa \& Ward (2009, 2010). No wireline log data exist for parasequence J, so the lithologic log is interpreted from core samples, on the Booligal Creek 1 well. The parasequence boundary shows change in core lithology from shale below the boundary to sandstone above the boundary (Fig. 6A).

4.2.3.2. Parasequence K. Parasequence K consists of the upper part of Winduck sequence 3 (WKS3) at the Kewell East 1 and Mount Emu 1 wells (Figs. 4, 5) and it is absent in the Booligal Creek 1 and 2 wells, on the northwestern flank of the Blantyre Sub-basin. Thickness in the western Neckarboo Sub-basin ranges from a maximum of $73 \mathrm{~m}$ in Kewell East 1 well to a minimum of about $62 \mathrm{~m}$ in the Mount Emu 1 well, in the central part of the Blantyre Sub-basin (Figs. 4, 5).

Wireline log signatures define the parasequence boundary (FS11), at the top of parasequence $\mathrm{K}$ throughout the Kewell East 1 and Mount Emu 1 wells. Wireline logs display an upward-fining parasequence $\mathrm{K}$, with the core lithology common to the two well sections characteristically associated with shale or thin silty shale beds below the boundary and sandstone beds above the boundary. Furthermore, the boundary of parasequence $\mathrm{K}$ is similar to the boundary between the base of Snake Cave and top of Winduck Intervals (unconformity) as defined by Khalifa (2005, 2006) and Khalifa \& Ward (2009, 2010).

\section{Discussion}

\subsection{Correlation of sequences and parasequences}

Fig. 7 is a well-log correlation showing the two criteria that are important for correlating the sequences and parasequences in the subsurface: (1) sedimentary facies observations in cuttings and core suggest that the latest Silurian to Early Devonian Winduck Interval is not characterized by significant facies variation between parasequences (Table 1 and Figs. 4-6A, B); and (2) the well-log signatures and characteristics of upward-coarsening and upward-fining parasequences bounded by flooding surfaces or sequence boundaries(Figs. 4-6A, B). Four of these parasequences form progradational and retrogradational parasequence sets bounded by major flooding surfaces (MFS). These major flooding surfaces can generally be correlated regionally, whereas the flooding surfaces bounding individual parasequences commonly can be correlated only locally (Figs. 4-6A, B).

Well logs are especially useful for correlation of the sandstone, shale and siltstone dominated intervals, which bound the parasequences A to K, and were used to help clarify the palaeogeography and distribution of sequences 1, 2 and 3. Preliminary correlations of flooding surfaces, maximum flooding surfaces and log markers (mainly sandstone and shale beds) identified in cores and interpreted on well-log correlation between the Blantyre and western Neckarboo Sub-basins reveal a distinct vertical change in stratigraphic architecture within the Winduck Interval. 
Well-log correlation in a detailed parasequence cross-section showing the Winduck sequence 1 is labelled WKS1 in Fig. 7. The sand-dominated parts of the Winduck sequence 1 are identified by inflections of gamma-ray and resistivity curves, which correspond to coarsening-upward trends (cf. Van Wagoner et al. 1990). Interpretation of a widespread sequence boundary is labelled WKSB1 within the study area. Winduck sequence 1 (WKS1) thus consists of four parasequences (A-D) forming a weakly to strongly progradational parasequence set (Fig. 7). A final progradational succession is represented by the coarsening-upward top part of Winduck sequence 1 (WKS1). The sequence is interpreted as a transgressive surface passing into a highstand systems tract. The vertical and lateral facies relationships, predicted rock types observed in core and wireline-log responses for individual parasequences A, B, C and D are interpreted to have been deposited in distributary channel sandstone complexes and distributary mouth bar successions as illustrated by Booligal Creek 1, 2, Mount Emu 1 and Kewell East 1 wells.

In Fig. 7 correlations between the four wells display irregular parasequence surfaces (FS1, FS2, FS3 and FS4) showing the prograding complex of parasequences A, $\mathrm{B}, \mathrm{C}$ and D. They are characterized by laterally continuous patterns in the western Neckarboo Sub-basin around Kewell East 1 well with genetically similar prograding complexes of parasequences in the central Blantyre Sub-basin around Mount Emu 1 well and around Booligal Creek 1 and 2 wells on the northwestern flank. However, parasequences A and B are absent from Booligal Creek 1 well (see Fig. 6A). The parasequence surfaces FS1 and FS2 form a prominent onlapping surface with the lower boundary of the Winduck sequence 1 (WKS1) around Booligal Creek 1 well (Fig. 7).

Winduck sequence 2 (WKS2) includes parasequences $\mathrm{E}$ to I. The sequence boundary (WKSB2) at the base of Winduck sequence 2 (WKS2) was picked from gammaray and resistivity wireline-log patterns that suggest an increase in sandstone upsection and it therefore, truncates the underlying unconformity in Booligal Creek 1 well. An angular unconformity is not discussed here (see Khalifa \& Ward 2009). However, a sequence boundary (WKSB2) can be correlated between well logs in the study area (Fig. 7). Sequence boundary 3 (WKSB3), as defined in these correlations, truncates the top of parasequences $\mathrm{H}$ and $\mathrm{I}$. Also, sequence boundary 3 (WKSB3), is marked by truncation of the underlying unconformity between Booligal Creek 1 and Booligal Creek 2 wells as shown in Figs. 6A, B.

The top of Winduck sequence 3 (WKS3) bounding unconformity (late Early Devonian) varies regionally, but shows erosional truncation of parasequences $\mathrm{H}$, J and $\mathrm{K}$ on the northwestern flank of the Blantyre Sub-basin. The top of the retrogradational log pattern commonly coincides with a high-gamma-ray marker within Kewell East 1 and Mount Emu 1 wells (Figs. 4, 5). The parasequence surfaces (FS8 and FS9) of the prograding in Winduck sequence 3 (WKS3), marked by onlap, disconformably overlie the sequence boundary (WKSB3) between Booligal Creek 2 and Kewell East 1 wells as shown in Fig. 7.

\subsection{Sequence stratigraphy versus lithostratigraphic units}

The sequence stratigraphic-lithostratigraphic model of the Winduck Interval study was initiated by detailed well-log correlation based on the following logs: gamma ray and resistivity. A composite log from Kewell East 1 well (Fig. 4) illustrates the identified boundaries and their relation to lithostratigraphy. Also, matching of lithologies observed in core samples to specific log responses allowed recognition of a range of well-log signatures characteristic of the three sequences and helped to provide the necessary control for the lithostratigraphic units. 
The sequence stratigraphic and lithostratigraphic model of the Winduck Interval in the Blantyre and western Neckarboo Sub-basins (Fig. 8) was constructed using the top of Winduck Interval or equivalent unconformities in each well as a datum (see Alder et al., 1998; Clark et al., 2001; Khalifa 2005; Khalifa \& Ward 2009). This horizon is a distinct lithologic break. It has a similar appearance in all of the wells (Mount Emu 1 and Kewell East 1) and is easy to identify on the wireline log signatures because it commonly is marked by an abrupt gamma ray and resistivity change (cf. Khalifa \& Ward 2009: Figs. 5, 12; Khalifa \& Ward 2010: Figs. 3, 14). Correlating the logs using this datum leads to an interpretation of continuous, relatively thin shale and shallow-marine sandstone stratigraphic section through the upper Winduck Interval in the Booligal Creek 1 and 2 wells (see Figs. 6A, B and the discussion above).

The sequence stratigraphic and lithostratigraphic model of the parasequence sets defines the high-resolution sequence stratigraphy of the Winduck Interval (Fig. 8). Their general character and internal sequence-lithostratigraphic unit architecture are described as follows.

Highstand systems tract; we have identified two main highstand systems tracts on the well-log correlation (Figs. 7, 8). The highstand systems tract (1) is represented by lithostratigraphic unit A and consists of a progradational parasequence set, composed of four parasequences (A to D) that rest on top of the sequence boundary (WKSB2).

The lower boundary of the highstand systems tract (HST-1) is defined by a sequence boundary (WKSB) that occurs below parasequence $\mathrm{A}$, at the bottom of lithostratigraphic unit A (Figs. 7, 8).

In the well-log correlation (Figs. 7,8 ) we interpreted the backstepping lower part of parasequence $\mathrm{E}$ near the top of the lithostratigraphic unit $\mathrm{A}$ as a transgressive systems tract (TST-1) forming approximately 30\% of Winduck sequence 2 (WKS2). It consists of parasequence E and facies association (B) "distributary-mouth bar deposits" in Booligal Creek 2 well to facies association (C) "tidal channel sand deposits” in Mount Emu 1 and Kewell East 1 wells, and represents the least developed and most areally restricted systems tract in Winduck sequence 2 (WKS2). Although the transgressive systems tract (1) thins and pinches-out around Booligal Creek 1 and 2 wells, the nature of the pinch-out is marked by onlap disconformably overlying the sequence boundary (WKSB2; Fig. 8). Parasequence $\mathrm{E}$ is strongly retrogradational relative to the underlying progradational parasequence set (parasequences $A$ to D, Fig. 7). Following the deposition of parasequence $\mathrm{E}$, the shoreline moved an unknown distance eastward and a transgressive surface (TS) cut the upper part of parasequence E (Figs. 7, 8). A maximum flooding surface (MFS) occurs approximately 5-10 m above parasequence E, representing the contact between lithostratigraphic unit A and the overlying lithostratigraphic unit B (Fig. 8). The top of parasequence $E$ is overlain by the highstand systems tract (2) (Figs. 7, 8), which consists of a progradational parasequence set within lithostratigraphic unit B. Also, highstand systems tract (2), forming approximately $70 \%$ of Winduck sequence 2 (WKS2), is composed of four parasequences (F to I), and rests on top of the sequence boundary (WKSB2).

The highstand systems tract (HST-2) is represented by several coarsening upward parasequences ( $\mathrm{F}$ to $\mathrm{I}$ ) of the progradational facies associations including facies association (B) as distributary mouth bar deposits, facies association (C) as tidal channel sand deposits and facies association (D) as proximal delta front associated with mouth bar deposits (Table 1, Figs. 4-6A, B). Parasequences thin upward but internally shaly siltstone and silty shale facies (facies WKE-8 and facies ME-5) thicken upwards. Sedimentary facies stacking indicates progradation toward the northwest with a shoreline located towards the east (Figs. 7, 8). HST-2 is erosionally truncated and overlain by transgressive 
facies of Winduck sequence 3 (WKS3), as seen high on the western side of the well log correlations around the Booligal Creek 1 and 2 wells (Fig. 8).

Winduck sequence 3 (WKS3), which is entirely penetrated by most of the borings, provides the best lithostratigraphic unit $C$ control on sequence thickness and siltstone, silty shale, shaly siltstone and shale distributions (Figs. 4-6A, B). The transgressive systems tract (2) of Winduck sequence 3 (WKS3) (Figs. 7, 8) is composed of thin backstepping parasequences $\mathrm{I}, \mathrm{J}$ and $\mathrm{K}$ in a retrogradational parasequence set. A maximum flooding surface (MFS) has not been identified in this systems tract. Only siltstones and very thin sandstones are preserved in the transgressive systems tract (TST-2). The medium-grained part of the transgressive systems tract (TST-2) was apparently truncated by the next stratigraphic boundary (top of Winduck Interval). Erosion of the transgressive systems tract (2) along the overlying stratigraphic boundary is common in many Tertiary sequences in the Booligal Creek 2 well, on the northwestern flank of the Blantyre Subbasin (cf. Khalifa \& Ward 2009: Figs. 8, 12).

\section{Conclusions}

The detailed description of the latest Silurian to Early Devonian Winduck Interval in the central part of the Darling Basin, embracing the Blantyre and western Neckarboo Sub-basins provides new information for understanding the lithostratigraphy and sequence stratigraphic correlations of the area. In this paper we present the first application of wireline-log signatures (gamma ray and resistivity) combined with core and cutting descriptions and limited biostratigraphic data that has enabled the construction of wirelinelog lithostratigraphic and sequence stratigraphic correlations and a sequence stratigraphiclithostratigraphic model for the Winduck Interval.

We proposed an informal stratigraphic framework for the Winduck Interval subsurface in the Blantyre and western Neckarboo Sub-basins in the central part of the Darling consisting of three lithostratigraphic units A, B and C, in ascending order as shown in Fig. 3. These lithostratigraphic units were correlated based on their lithologic features as interpreted from gamma ray and resistivity well logs supplemented by core and cutting data. These lithostratigraphic units constitute significant divisions of the Winduck Interval and facilitate regional mapping.

Application of the sequence stratigraphic approach has improved our understanding of the latest Silurian to Early Devonian subsurface Winduck Interval in the Blantyre and western Neckarboo Sub-basins. Three key stratigraphic surfaces have been identified in this study area (Fig. 7): (a) sequence boundaries (WKSB1, WKSB2 and WKSB3); (b) parasequences boundaries (FS1-FS11) as minor flooding surface and (c) maximum flooding surface (MFS). The Winduck Interval is characterised by three major sequences (Winduck sequences 1 to 3 ) that consist of four parasequence sets and ten parasequences. Winduck sequence 1 (WKS1) consists of one progradational parasequence set (one coarsening upward) and four parasequences (A, B, C and D). Winduck sequence 2 (WKS2) consists of one retrogradational parasequence set and one progradational parasequence set (fining upward to coarsening upward) and parasequences (E, F, G, H and I). Finally, Winduck sequence 3 (WKS3) consists of one retrogradational parasequence set (fining upward) and the last two parasequences ( $\mathrm{J}$ and $\mathrm{K}$ ).

Fig. 8 provides a sequence stratigraphic-lithostratigraphic model for the Winduck Interval in the Blantyre and western Neckarboo Sub-basins. Their general character and internal sequence-lithostratigraphic unit architecture are described as follows:

- Highstand systems tract. We have identified two main highstand systems tracts based on well-log correlation. The highstand systems tract, (1) 
represented by the lithostratigraphic unit, forms $70 \%$ of interval A. Also, the lower boundary of the highstand systems tract (HST-1) is defined by the sequence boundary (WKSB) that occurs below parasequence $\mathrm{A}$, at the bottom of lithostratigraphic unit A.

- We interpreted the backstepping lower part of parasequence E near the top of the lithostratigraphic A as forming a transgressive systems tract (TST-1) constituting approximately $30 \%$ of Winduck sequence 2 (WKS2). This is the most areally restricted systems tract in the Winduck sequence 2 (WKS2). Although transgressive systems tract (1) thins and pinches-out around Booligal Creek 1 and 2 wells, the nature of the pinch-out is marked by an onlap disconformably overlying the sequence boundary (WKSB2). A maximum flooding surface (MFS) occurs approximately 5-10 m above parasequence $\mathrm{E}$, representing the contact between lithostratigraphic unit $\mathrm{A}$ and the overlying lithostratigraphic unit $\mathrm{B}$. The top of parasequence $\mathrm{E}$ is overlain by the highstand systems tract (2). Also, highstand systems tract (2) forms approximately 70\% of Winduck sequence 2 (WKS2) and is composed of four parasequences (F, G, H and I) resting on top of the sequence boundary (WKSB2).

- Winduck sequence 3 (WKS3), which is entirely penetrated by most of the wells, provides the best lithostratigraphic control on sequence thickness and siltstone, silty shale shaly siltstone and shale distributions. The transgressive systems tract (2) of Winduck sequence 3 (WKS3) is composed of thin backstepping parasequences $\mathrm{I}, \mathrm{J}$ and $\mathrm{K}$ in a retrogradational parasequence set. A maximum flooding surface (MFS) has not been identified in this systems tract. Only siltstones and very thin sandstones are preserved in the transgressive systems tract (TST-2). Erosion of the transgressive systems tract (2) by the overlying stratigraphic boundary is common in many Tertiary sequences in Booligal Creek 2 well on the northwestern flank of the Blantyre Sub-basin.

\section{Acknowledgements}

We thank Geological Survey of NSW, NSW Trade \& Investment (Petroleum Geoscience) for support of this research and for permission to publish. Special thanks to Jola Jaworska (Acting Manager - Petroleum Geoscience) and M.A.J. Wark (contractor Coal \& Petroleum Geoscientist) for providing all of the data and reports for this research. Thanks also to Dr Jack Grant-Mackie (The University of Auckland) for raising some useful issues in his review of this article. We are grateful to the editor and referees for their constructive criticism to an early version of the article, discussions, and helpful comments, which were of great aid.

\section{References}

ALDER J. D., BEMBRICK C., HARTUNG-KAGI B., MULLARD B, PRATT D. A. SCOTT J. and SHAW R. D. 1998. A re-assessment of the petroleum potential of the Darling Basin: a Discovery 2000 initiative. The APEA Journal 38, 278-310. 
ALEALI, M., RAHIMPOUR-BONAB, H., MOUSSAVI-HARAMI, R. and JAHANI, D., 2013. Environmental and sequence stratigraphic implications of anhydrite textures: A case from the Lower Triassic of the Central Persian Gulf. Journal of African Earth Sciences 75, 110-125.

ANDREWS, E. C., 1913. The Canbelego, Budgery, and Budgerygar mines. Part I of the Cobar Copper and Gold field. Geological Survey of New South Wales, Sydney, Mineral Resources 17, 207.

BEMBRICK C. S. 1997a. A re-assessment of the Darling Basin Devonian sequence. Geological Survey of New South Wales, Sydney Quarterly Notes 105, 1-16.

BEMBRICK C. S. 1997b. The Darling Basin Devonian sequence - a reappraisal preliminary report. Geological Survey of New South Wales Open-File Report GS1997/214.

BYRNES J. G. 1985. Petroleum data package Darling region New South Wales. Geological Survey of New South Wales Open-File Report GS1985/009.

DUARTE, L. V. 2007. Lithostratigraphy, sequence stratigraphy and depositional setting of the Pliensbachin and Toarcian series in the Lusitanian Basin, Portugal. Ciências da Terra, http://hdl.handle.net/10362/4788.

CLARK N. R., MOFFITT R. S. and SHAW R. D. 2001. Kewell East 1 well completion report. Geological Survey of New South Wales Open-File Report GS2001/418.

COONEY P. M., MANTARING A. M. 2007. The petroleum potential of the Darling Basin: In: Munson T. J. and Ambrose G. J. (eds), Proceedings of the Central Australian Basins Symposium (CABS), Alice Springs, Northern Territory, 16-18 August, 2005. Northern Territory Geological Survey, Special Publication 2 (Preliminary Edition).

EL HAFID BOUOUGRIA and ALI SAQUAQUEB 2004. Lithostratigraphic framework and correlation of the Neoproterozoic northern West African Craton passive margin sequence (Siroua-Zenaga-Bouazzer Elgraara Inliers, Central Anti-Atlas, Morocco): an integrated approach. Journal of African Earth Sciences 39, 227-238.

EMERY D. and MYERS K. J. 1996. Sequence Stratigraphy: Blackwell Science, Oxford, United Kingdom.

EVANS P. R. 1977. Petroleum geology of western New South Wales. The APEA Journal 17, 42-49.

GALLOWAY W. E. 1989. Genetic stratigraphic sequences in basin analysis: architecture and genesis of flooding-surface-bounded depositional units: American Association of Petroleum Geologists Bulletin 73, 125-142.

GLEN R. A. 1979. The Mulga Downs Group and its relation to the Amphitheatre Group southwest of Cobar. Geological Survey of New South Wales Quarterly Notes 36, 110.

GLEN R. A. 1982a. Nature of Late Early to Middle Devonian tectonism in the Buckambool area, Cobar, New South Wales. Journal of the Geological Society of Australia 28, 127-38.

GLEN R. A. 1982b. The Amphitheatre Group, Cobar, and New South Wales: preliminary results of new mapping and implications for ore search. Geological Survey of New South Wales Quarterly Notes 49, 1-14.

GLEN R. A. 1986. Geology of the Wrightville 1:100 000 Sheet 8034. Geological Survey of New South Wales, Sydney.

GLEN R. A. 1991. Inverted transtensional basin setting for gold and copper and base metal deposits at Cobar, New South Wales. BMR Journal of Australia Geology \& Geophysics 12, 13-24. 
GLEN, R.A., CLARE, A.P. and SPENCER, R. 1996. Extrapolating the Cobar Basin model to the regional scale: Devonian basin-formation and inversion in western New South Wales. in the Cobar Mineral Field - A 1996 perspective, Cook, W.G., Ford, A.J.H., McDermott, J.J., Standish, P.N., Stegman, C.L. and Stegman, T.M., (eds). Australian Institute of Mining and Metallurgy, Melbourne, Spectrum Series 3/96, 43-83.

HASKELL T. R. and WILTSHIRE M. J. 1970. NSW Oil \& Gas-Mount Emu 1 well completion report. Geological Survey of New South Wales Open-File Report WCR146.

JESSOP R. and COWAN-LUNN R. 1996a. Booligal Creek 1 well completion report. Geological Survey of New South Wales Open-File Report WCR146.

JESSOP R. and COWAN-LUNN R. 1996b. Booligal Creek 2 well completion report. Geological Survey of New South Wales Open-File Report WCR146.

KHALIFA M. KH., 2005. Geological and geophysical evaluation and interpretation of the Blantyre Sub-basin, Darling Basin, New South Wales. PhD thesis, University of New South Wales, Sydney (unpubl.).

KHALIFA M. KH. 2006a. High-resolution subsurface stratigraphy of the Blantyre Subbasin using seismic data and well logs. The Petroleum Exploration Society of Australia News 84, 102-110.

KHALIFA, M. KH., 2006b. Seismic sedimentological analysis and lithofacies framework of the Mulga Downs Group in the Blantyre Sub-basin, Darling Basin. The Petroleum Exploration Society of Australia News 85, 59-63.

KHALIFA, M. KH., 2009. Tectonostratigraphic evolution of the Blantyre Sub-basin and adjacent regions, New South Wales, based on integration of seismic, gravity and well data. Journal and Proceedings of the Royal Society of New South Wales 142, 29-56.

KHALIFA M. KH. 2010. Correlation of the Devonian formations in the Blantyre Subbasin, New South Wales with the Adavale Basin, Queensland. Journal and Proceedings of the Royal Society of NSW 143, 19-33.

KHALIFA M. KH. and ALI MANGI(unpubl.). ALTA'EE 2011. An integrated petrophysical analysis to evaluate sequence stratigraphy of the Winduck Interval in the Neckarboo Sub-basin, Darling Basin, NSW. Paper SPE 148108, 23th SPE Asia Pacific Oil \& Gas Conference and Exhibition (APOGCE), Jakarta, Indonesia, 20 - 22 September 2011.

KHALIFA M. KH. and WARD C. R. 2009. Stratigraphic correlation of the Devonian sequence in the Blantyre Sub-basin, Darling Basin, western New South Wales. Australian Journal of Earth Sciences 56, 111-133.

KHALIFA M. KH. \& WARD C. R. 2010. Sedimentological Analysis of the Subsurface Mulga Downs Group in the central part of the Darling Basin, western New South Wales. Australian Journal of Earth Sciences 57, 111-139.

KHALIFA, M. KH., JONES, B. G. and HLAL, O., in pers. comm. Sedimentary facies analysis and palaeogeographic significance of the subsurface latest Silurian to Early Devonian Winduck Interval in the Blantyre and western Neckarboo Subbasins, Darling Basin, western New South Wales, Australia. Submitted to Quaternary Science Reviews.

MEOR H.A.H., HOWARD D.J., PETER A.A. and WAN HASIAH, A. 2013. Sedimentology and stratigraphic development of the upper Nyalau Formation (Early Miocene), Sarawak, Malaysia: A mixed wave- and tide-influenced coastal system. Journal of Asian Earth Sciences 76, 301-311. 
NADON, G. C., (TONI) SIMO, J. A., DOTT, JR., R. H. and BYERS, C. W. 1984. HighResolution Sequence Stratigraphic Analysis of the St. Peter Sandstone and Glenwood Formation (Middle Ordovician), Michigan Basin, U.S.A. AAPG Bulletin, 84, 975-996.

NEEF G. and BOTTRILL R. S. 1991. Early Devonian (Gedinnian) nomarine strata present in a rapidly subsiding basin in far western New South Wales, Australia. Sedimentary Geology 71, 195-212.

NEEF G. 2004. Stratigraphy, sedimentology, structure and tectonics of Lower Ordovician and Devonian strata of South Mootwingee, Darling Basin, western New South Wales. Australian Journal of Earth Sciences 41, 15-29.

NEEF G. 2005. Devonian-Carboniferous structure and tectonics at Maccullochs Range, and the recognition of the Darling Basin Conjugate Fault System showing switching of the directions of principal horizontal stress. Australian Journal of Earth Sciences 52, 315-326.

NEEF G. EDWARDS A. C. BOTTRILL R. S. HATTY J. HOLZBERGER I. KELLY R. and VAUGHAN J. 1989. The Mt Daubeny Formation: Arenite-rich, ? Late Silurian-Early Devonian (Gedinnian) strata in far western New South Wales. Journal and Proceedings of the Royal Society of New South Wales 122, 97-106.

NEEF G., LARSEN D. F. and RITCHIE A. 1996. Late Silurian and Devonian fluvial strata in western Darling Basin, far West New South Wales. Geological Society of Australia Sedimentologists Group Field Guide Series 10.

PEARSON P. 2003. Darling Basin SEEBASE ${ }^{\mathrm{TM}}$ Project by SRK Consulting. Geological Survey of New South Wales Open-File Report GS2006/146.

PEDERSEN, P.K. 2003. Stratigraphic relationship of Alderson (Milk River) strata between the Hatton and Abbey-Lacadena pools, southwestern Saskatchewan preliminary observations. Saskatchewan Geological Survey, Volume 1, Sask. Industry Resources, Misc. Rep. 2003-4.1, CD-ROM, Paper A-11, 11p.

POSAMENTIER H. W. and VAIL P. R. 1988. Eustatic controls on clastic deposition. II. Sequence and systems tract models. In: Wilgus C. K., Hastings B. S., Kendall C. G. St. C., Posamentier H. W., Ross C. A. \& Van Wagoner J. C. eds. Sea Level Changes - An Integrated Approach: SEPM Special Publication 42, 125-154.

RAYNER E. O. 1962. The mineralogy and genesis of the iron-rich copper ores of the Cobar province, New South Wales. PhD thesis, University of New South Wales, Sydney, (unpubl.).

READING H. G. 1986. Sedimentary environments and facies (2nd edition). Blackwell Scientific Publications, Oxford.

REINECK H. E. and SINGH I. B. 1980. Depositional sedimentary environments, with reference to terrigenous clastics (2nd edition). Springer, New York.

RIDER M. H. 2002. The geological interpretation of well logs (Second edition). RiderFrench Consulting Ltd.

SCHEIBNER, E., 1993. Structural framework of New South Wales. The Geological Survey of New South Wales Quarterly Notes 93, 1-35.

SELLEY R. C. 1985. Ancient sedimentary environments and their subsurface diagnosis (2nd edition). Chapman \& Hall, London.

SLATT R. M. 2006. Stratigraphic reservoir characterization for petroleum geologists, geophysicists, and engineers (first edition). Elsevier Publication. 
VAN WAGONER J. C., POSAMENTIER H. W., MITCHUM R. M., VAIL P. R., SARG J. F. LOUTIT T. S. and HARDENBOL J. 1988. An overview of the fundamentals of sequence stratigraphy and key definitions. In: Wilgus C. K., Hastings B. S., Kendall C. G. St. C., Posamentier H. W., Ross C. A. \& Van Wagoner, J. C. (ed.): Sea-level changes: an integrated approach, Society of Economic Paleontologists and Mineralogists, 42, 38-45.

VAN WAGONER J. C., MITCHUM JR., R. M., CAMPION K. M. and RAHMANIAN V. D. 1990. Siliciclastic sequence stratigraphy in well logs, core, and outcrops: concepts for high-resolution correlation of time and facies. American Association of Petroleum Geologists Methods in Exploration Series 7, 55 pp.

WARD C.R., WRIGHT-SMITH, G.N. and TAYLOR, N.F., 1969. Stratigraphy and structure of the north-west part of the Barrier Ranges of New South Wales. Journal and Proceedings of the Royal Society of New South Wales 102, 55-71

WILLCOX J. B., YEATES A. N., MEIXNER T., SHAW R., ALDER J. D. 2003. Structural evolution and potential petroleum plays in the Darling Basin: (Pondie Range Trough - Mount Jack Area) Based on a seismic sequence analysis. Geoscience Australia Record, 2003/05. 


\section{List of Figures:}

Fig. 1. (A) Geographical location map of New South Wales showing the location of the Darling Basin. (B) Overview map of Darling Basin showing the distribution of the main structural elements and major structural zones, sub-basins and troughs with location of the study area denoted by the box (modified after Glen et al., 1996, Scheibner, 1993 and khalifa, 2010). (C) Index map showing gravity anomaly with distribution of wells drilled and location of wells used in cross sections (Figs. 7 and 8) within the Blantyre and western Neckarboo Sub-basins as discussed in the text (modified after NSW Department of Mineral Resources, 2003; Khalifa, 2005, 2009). Abbreviations: anticlines H-1, H-2 and dome H-3 = structural lows; synclines L-1 and L-2 = structural lows, practically all features also occur in structural highs and lows as discussed by Khalifa $(2005,2009)$.

Fig. 2. (A) lithostratigraphic unit subdivisions and equivalents of the latest Silurian to Early Devonian in the Darling Basin, western New South Wales (modified after Khalifa 2005; 2006a,b; 2009, 2010; Khalifa \& Ward 2009), including seismic marker unconformities (A and B) of Evans (1977) and Winduck Interval defined by Bembrick (1997a,b). (B) Depositional environments framework of the latest Silurian to Early Devonian Winduck Interval from west to east Darling Basin, western New South Wales (modified after Alder et al 1998; Pearson 2003; Khalifa 2005, 2006a,b, 2009, 2010; Khalifa \& Ward 2009), including seismic marker unconformities (A and B) of Evans (1977) and Winduck Interval defined by Bembrick (1997a, b).

Fig. 3. NW-E subsurface stratigraphic section through the Winduck Interval from Blantyre and western Neckarboo Sub-basins showing the three major lithostratigraphic units (A, C and B) defined by wireline-log marker correlation and top of unit A is used as horizontal lithostratigraphic datum (refer to text for discussion). The logs for each well (Kewell East 1 and Mount Emu 1) contain both a gamma-ray (GR) and a resistivity (RES), logs. Lithologic information (fully cored description from Kewell East 1, Booligal Creek 1 and Booligal Creek 2 tie wells) has been added to the logs to aid in correlation; however, correlation is made primarily on the basis of the "signatures" of the wireline-log curves (see the location of the section in Fig. 1C).

Fig. 4. Sequence stratigraphic interpretation for the latest Silurian to Early Devonian Winduck Interval in Kewell East 1 well, western Neckarboo Sub-basin. The well section is based on interpretation of gamma ray and resistivity logs, fully cored, lithology, sedimentary facies, facies associations and lithostratigraphic units used in this study (refer to text for discussion). See Fig. 1C for location the Kewell East 1 well. Abbreviations: TST $=$ transgressive systems tract; HST = highstand systems tract; TS = transgressive surface; MFS = maximum flooding surface; FS = flooding surface; PS = parasequence; WKSB = sequence boundary; LB = lower boundary of the lithostratigraphic unit.

Fig. 5. Sequence stratigraphic interpretation for the latest Silurian to Early Devonian Winduck Interval in Mount Emu 1 well within Blantyre Sub-basin. The well section is based on interpretation of gamma ray and resistivity logs, cutting samples, lithology, sedimentary facies, facies associations and lithostratigraphic units used in this study (refer to text for discussion). See Fig. 1C for location the Mount Emu 1 well. Abbreviations: $\mathrm{TST}=$ transgressive systems tract; HST $=$ highstand systems tract; $\mathrm{TS}=$ transgressive surface; MFS = maximum flooding surface; FS = flooding surface; PS = parasequence; WKSB = sequence boundary; LB = lower boundary of the lithostratigraphic unit. 
Fig. 6. (A) Sequence stratigraphic interpretation for the latest Silurian to Early Devonian Winduck Interval in Booligal Creek 1 well, northwestern flank of the Blantyre Sub-basin Mount Emu 1 well in Blantyre Sub-basin and (B) Sequence stratigraphic interpretation for the latest Silurian to Early Devonian Winduck Interval in Booligal Creek 2 well, northwestern flank of the Blantyre Sub-basin. These well sections are based on fully cored; lithology, sedimentary facies, facies associations and lithostratigraphic units used in this study (refer to text for discussion). See Fig. 1C for location the Booligal Creek 1 and 2 wells. Abbreviations: TST $=$ transgressive systems tract; HST $=$ highstand systems tract; TS = transgressive surface; MFS = maximum flooding surface; FS = flooding surface; PS $=$ parasequence; WKSB = sequence boundary; LB = lower boundary of the lithostratigraphic unit.

Fig. 7. Regional wireline-log correlation panel depicting the sequence stratigraphic interpretation of the latest Silurian to Early Devonian Winduck Interval in the Blantyre and western Neckarboo Sub-basins in the central part of the Darling. Stratigraphic correlation through Booligal Creek 1, Booligal Creek 2, Mount Emu1 and Kewell East 1 wells showing of gamma-ray and resistivity log profiles and, core and cutting data descriptions (See the location of the section in Fig. 1C). Individual parasequences (identified by abbreviation words) are bounded by marine flooding surfaces (FS1-FS11). Datum is the top of Winduck Interval as defined by Khalifa (2005) and Khalifa \& Ward (2009). The maximum flooding surface (MFS) at the top of parasequence $E$ which is overlain by Winduck sequence 2 (WKS2) and the letters in parentheses associated with the sequence name indicate Winduck Interval nomenclature used by Bembrick (1997a, b). WKS1 to WKS3 = Winduck sequences 1 through 3 (refer to text for discussion).

Fig. 8. Sequence stratigraphic-lithostratigraphic model of Winduck Interval in Blantyre and western Neckarboo Sub-basins (refer to text for discussion). Datum is the top of Winduck Interval as defined by Khalifa (2005) and Khalifa \& Ward (2009). Abbreviations: WKS1 $=$ Winduck sequences 1 ; WKS2 $=$ Winduck sequences 2; WKS3 = Winduck sequence 3; HST = transgressive systems tract; TST = transgressive systems tract; TS = transgressive surface; MFS = maximum flooding surface; LB = lower boundary of the lithostratigraphic units A through C. Kewell East 1 and Mount Emu1 is key well evaluated in this model. See the location of the section in Fig. 1C. 
Table 1: Summary of facies associations and interpreted depositional environments identified in the sequence stratigraphic interpretation

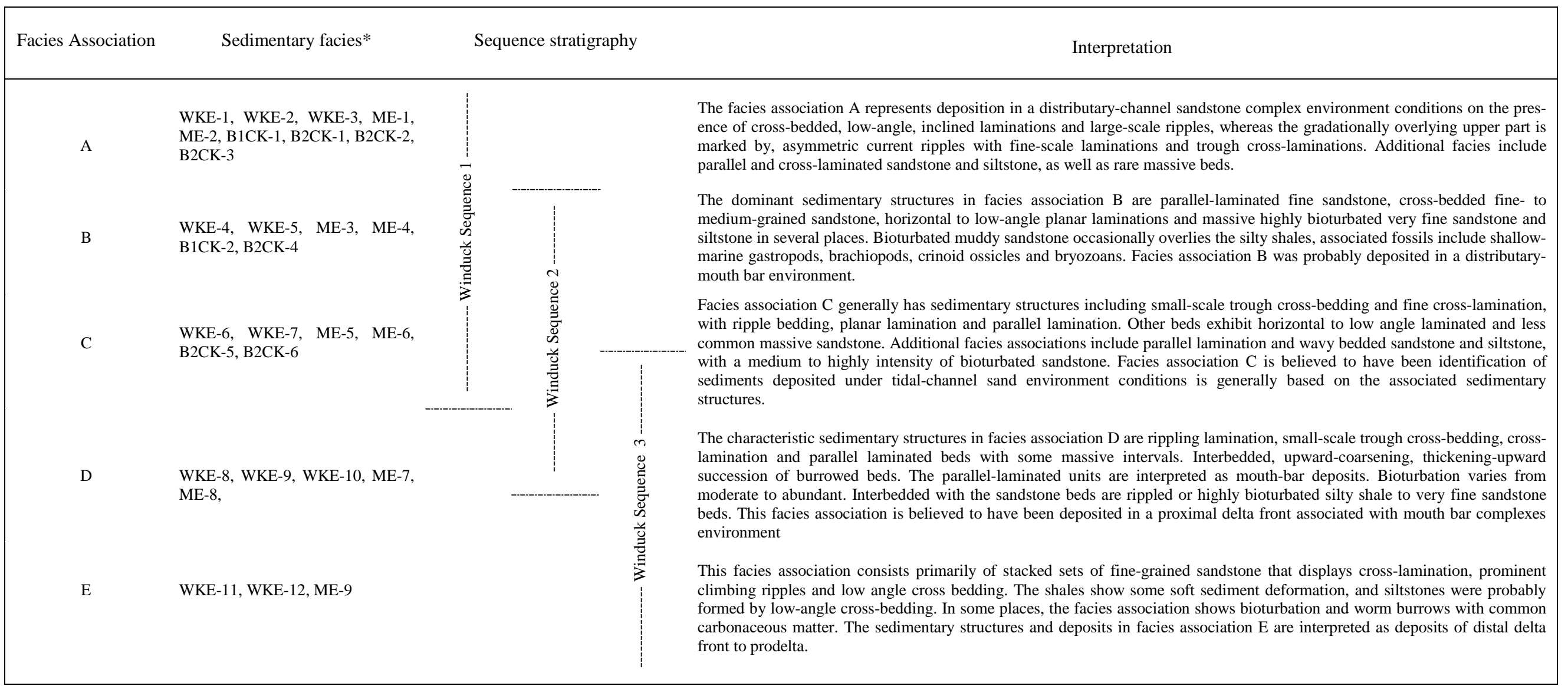

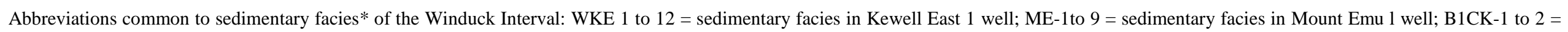
sedimentary facies in Booligal Creek 1well; B2CK-1to 6 = sedimentary facies in Booligal Creek 2 well as identified by Khalifa, Brian and Hlal, pers. comm. 
Table 2: The stratigraphic of the latest Silurian to Early Devonian Winduck Interval well penetrations and data used in the study.

\begin{tabular}{|c|c|c|c|c|c|c|c|c|c|c|c|}
\hline Well & $\begin{array}{l}\mathrm{KB} . \\
\text { (metres) }\end{array}$ & $\begin{array}{l}\text { TD. } \\
\text { (metres) }\end{array}$ & $\begin{array}{l}\text { Lithostratigraphic Interval } \\
\text { described by Bembrick (1997a, b) }\end{array}$ & $\begin{array}{l}\text { Top } \\
\text { (metres) }\end{array}$ & $\begin{array}{l}\text { Bottom } \\
\text { (metres) }\end{array}$ & $\begin{array}{l}\text { Thickness } \\
\text { (metres) }\end{array}$ & Types of data available & $\begin{array}{l}\text { Latitude } \\
\left({ }^{\circ} \mathrm{S}\right)\end{array}$ & $\begin{array}{l}\text { Longitude } \\
\left({ }^{\circ} \mathrm{E}\right)\end{array}$ & Area & Author \\
\hline Mount Emu 1 & 80.2 & 1450.5 & & 612 & 1450.5 & 838.5 & $\begin{array}{l}\text { Wireline logs: gamma ray, sonic, } \\
\text { resistivity. } \\
\text { Samples: three cores and cutting. } \\
\text { Biostratigraphic data. } \\
\text { Well completion report: hard copy } \\
\text { and digital. }\end{array}$ & -32.33 & 143.54 & 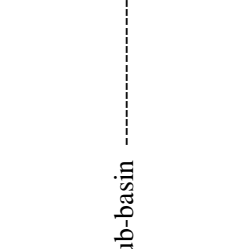 & $\begin{array}{l}\text { Khalifa (2005, 2009, } \\
\text { 2010) and Khalifa \& } \\
\text { Ward (2009) }\end{array}$ \\
\hline Booligal Creek 1 & 80.2 & 409.5 & 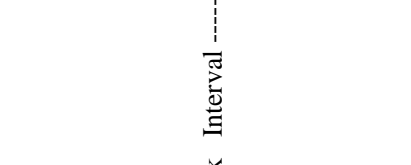 & 260 & 409.5 & 149.5 & $\begin{array}{l}\text { Samples: fully cored. } \\
\text { Well completion report: hard copy } \\
\text { and digital. }\end{array}$ & -31.85 & 143.23 & 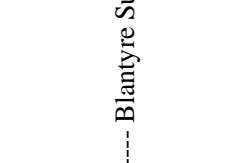 & $\begin{array}{l}\text { Khalifa }(2005,2009 \text {, } \\
\text { 2010) and Khalifa \& } \\
\text { Ward (2009) }\end{array}$ \\
\hline Booligal Creek 2 & 80.2 & 761.4 & 递 & 238 & 761.4 & 523.4 & $\begin{array}{l}\text { Samples: fully cored. } \\
\text { Well completion report: hard copy } \\
\text { and digital. }\end{array}$ & -31.83 & 143.23 & & \\
\hline Kewell East 1 & 79.9 & 1224 & & 378 & 1224 & 846 & $\begin{array}{l}\text { Wireline logs: gamma ray, sonic, } \\
\text { resistivity. } \\
\text { Samples: fully cored. } \\
\text { Biostratigraphic data. } \\
\text { Well completion report: hard copy } \\
\text { and digital. }\end{array}$ & -32.08 & 144.01 & $\begin{array}{l}\text { Western Neckaboo } \\
\text { Sub-basin }\end{array}$ & Clark et al (2001) \\
\hline
\end{tabular}


Table 3: Winduck Interval showing the three lithostratigraphic units defined in this study as compared to stratigraphic divisions recognized in section well penetrations in the study area.

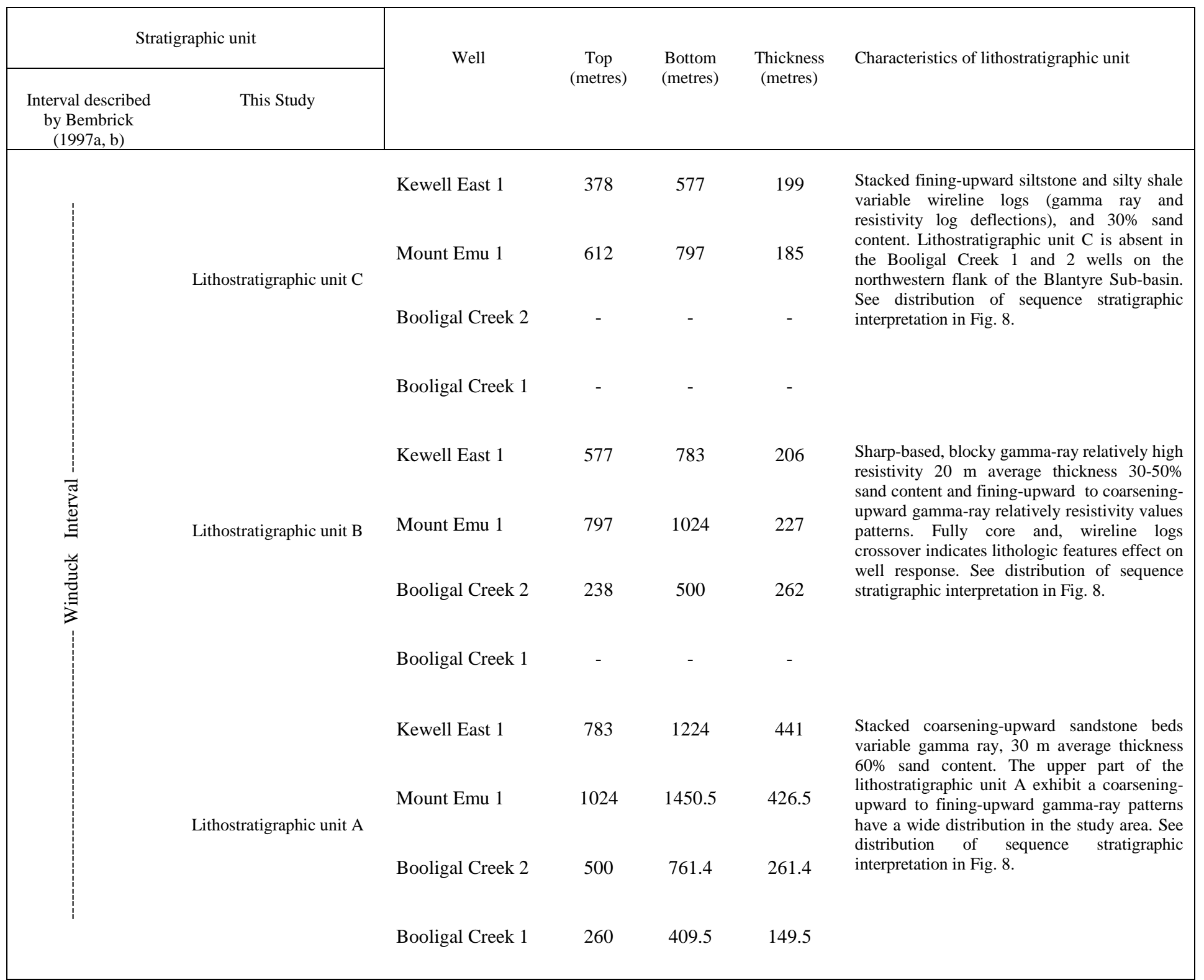



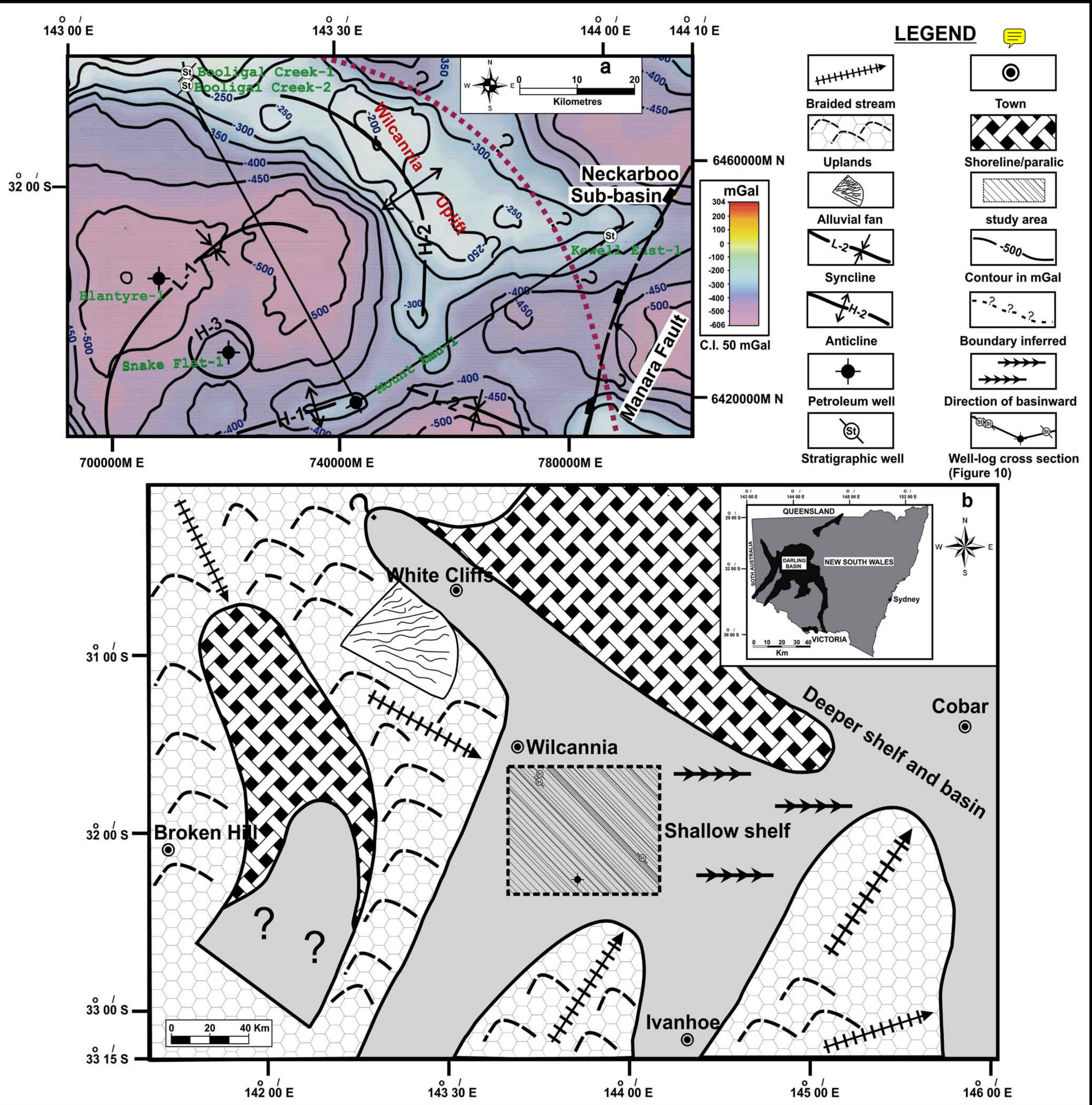


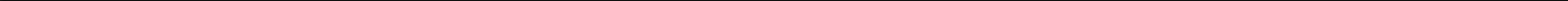




$$
\text { west- } \frac{15}{1 ! p}
$$

EARLY DEVONIAN AND LATEST SILURIAN . Seismic Horizon-A fluvial meandering . $\quad$. $\quad$ stréám Mt Daubery Formation

Deltaic

Winduck Group Fluvial' braided streán

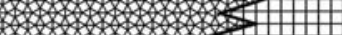
Lyval braided strea

2 - 2 Amphiteatre Brgén Hill \& Wono 


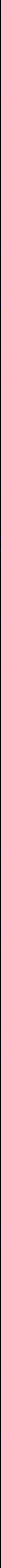



LITHOLOGY AND SEDIMENTARY STRUCTURES

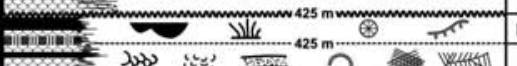

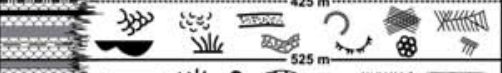

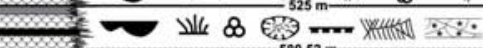

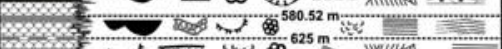

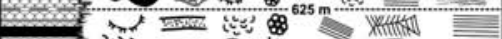

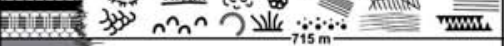

ufinifer

cosecosectis.

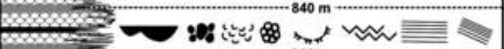

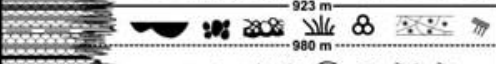

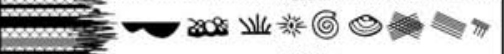

20

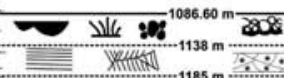

$\because \approx m$

\begin{tabular}{|c|c|c|}
\hline FACIES & SUBFACIES & FACIES ASSOCIATION \\
\hline Facies WKE-12 & & \multirow[b]{2}{*}{ Facies Association E } \\
\hline Facies WKE-11 & & \\
\hline Facies WKE-10 & & \multirow{4}{*}{ Facies Association D } \\
\hline Facies WKE-9 & & \\
\hline \multirow{2}{*}{ Facies WKE-8 } & racies woke-se & \\
\hline & Faciet woeses & \\
\hline \multirow{2}{*}{ Facies WKE-7 } & Focies wore-re & \multirow{3}{*}{ Facies Association C } \\
\hline & Facien Wre-7A & \\
\hline Facies WKE-6 & & \\
\hline Facies WKE-5 & & \multirow[b]{2}{*}{ Facies Association B } \\
\hline Facies WKE-4 & & \\
\hline Facies WKE-3 & & \multirow[b]{2}{*}{ Facies Association A } \\
\hline Facies WKE-2 & 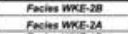 & \\
\hline
\end{tabular}

ENVIRONMENTS

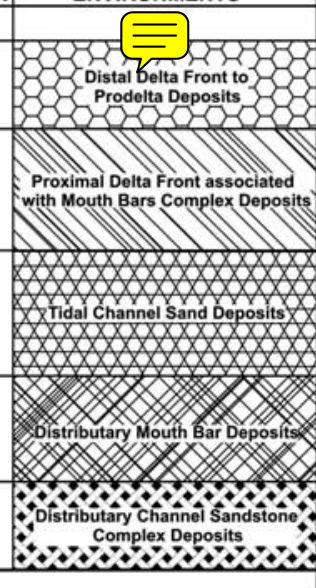







LITHOSTRATIGRAPHIC UNITS

Snake Cave Interval

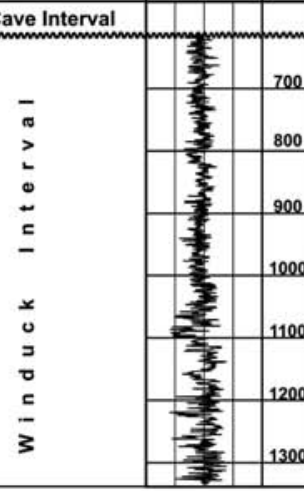

NTERPRETATIONS

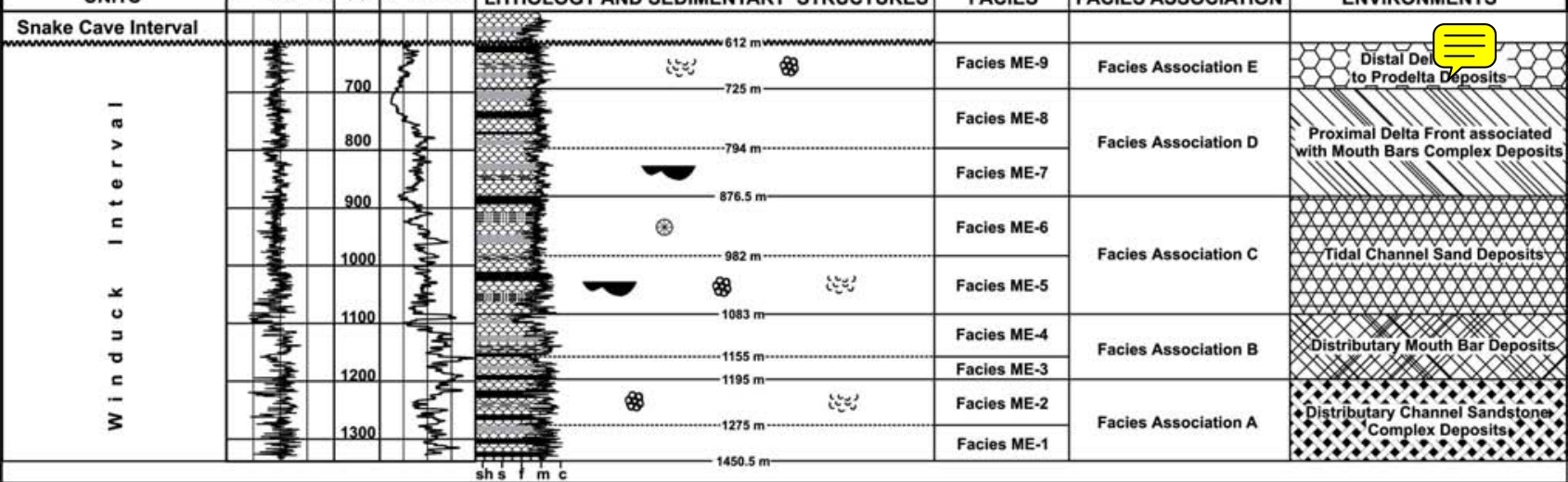

LITHOLOGY AND SEDIMENTARY STRUCTURES

FACIES FACIES ASSOCIATION

ENVIRONMENTS 


\section{LITHOSTRATIGRAPHIC UNITS}

Snake Cave Interval

Winduck Interval
INTERPRETATIONS

a
CORE

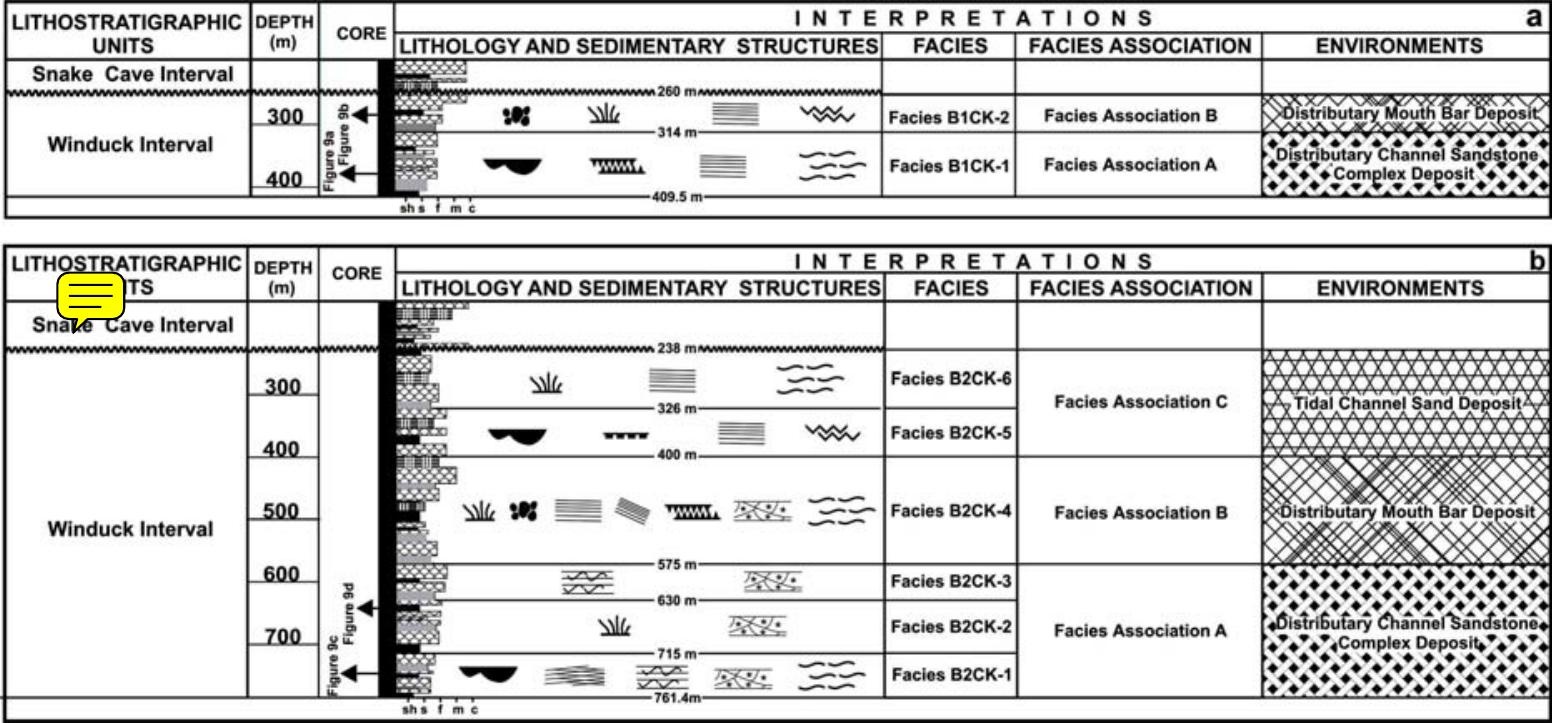

\section{FACIES ASSOCIATION}

Facies Association A

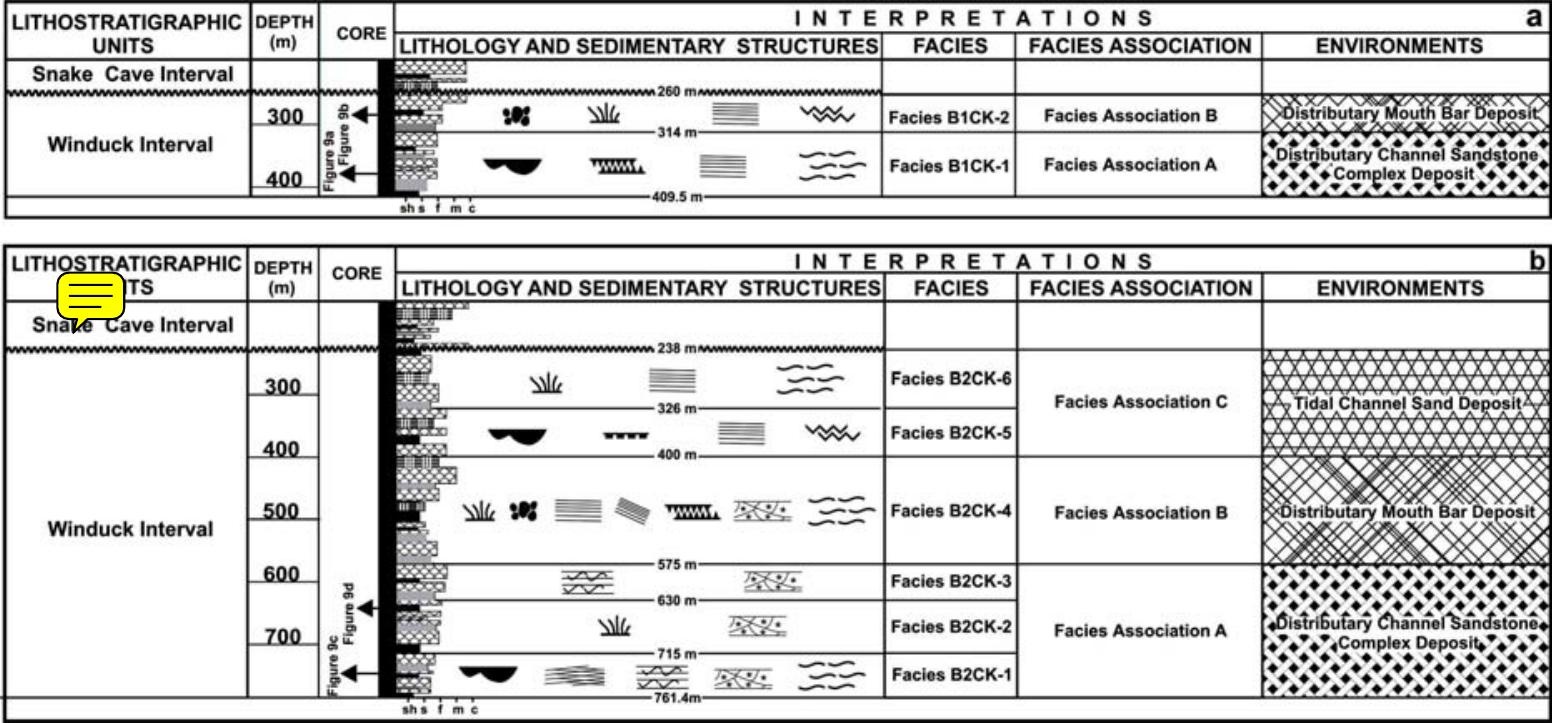

Facies Association B

I N T ERPRET T T I O N S

LITHOSTRATIGRAPHIC

三 TS

Snake Cave Interval

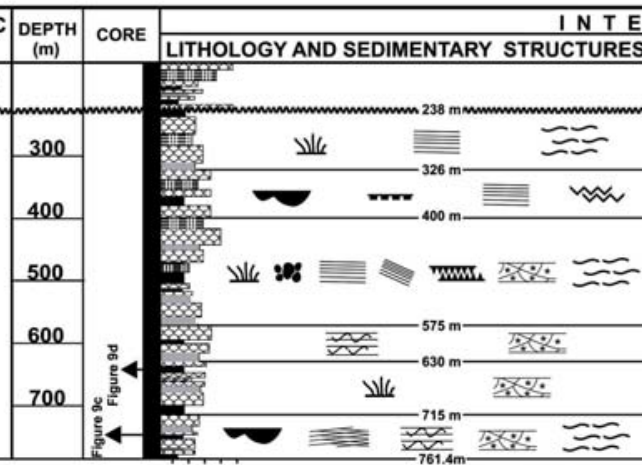

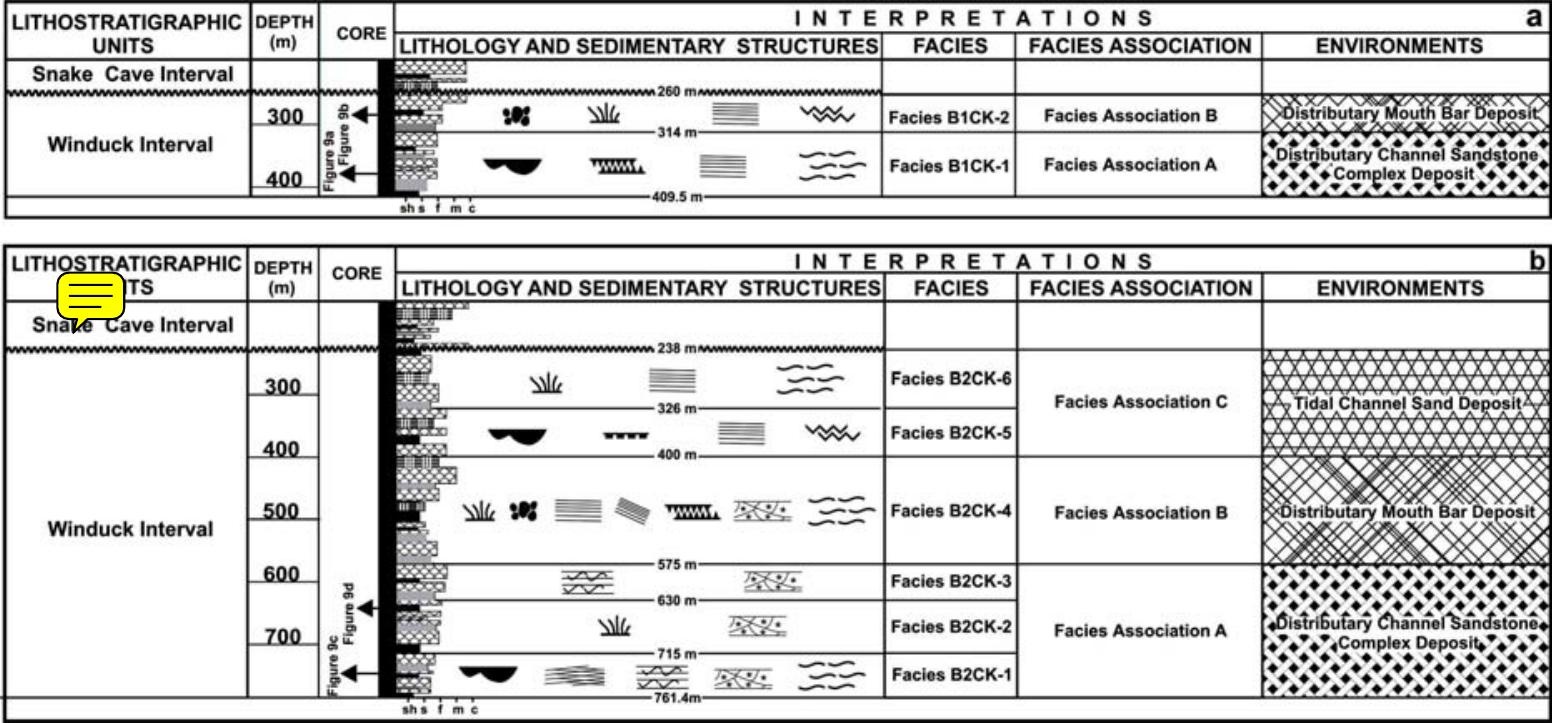

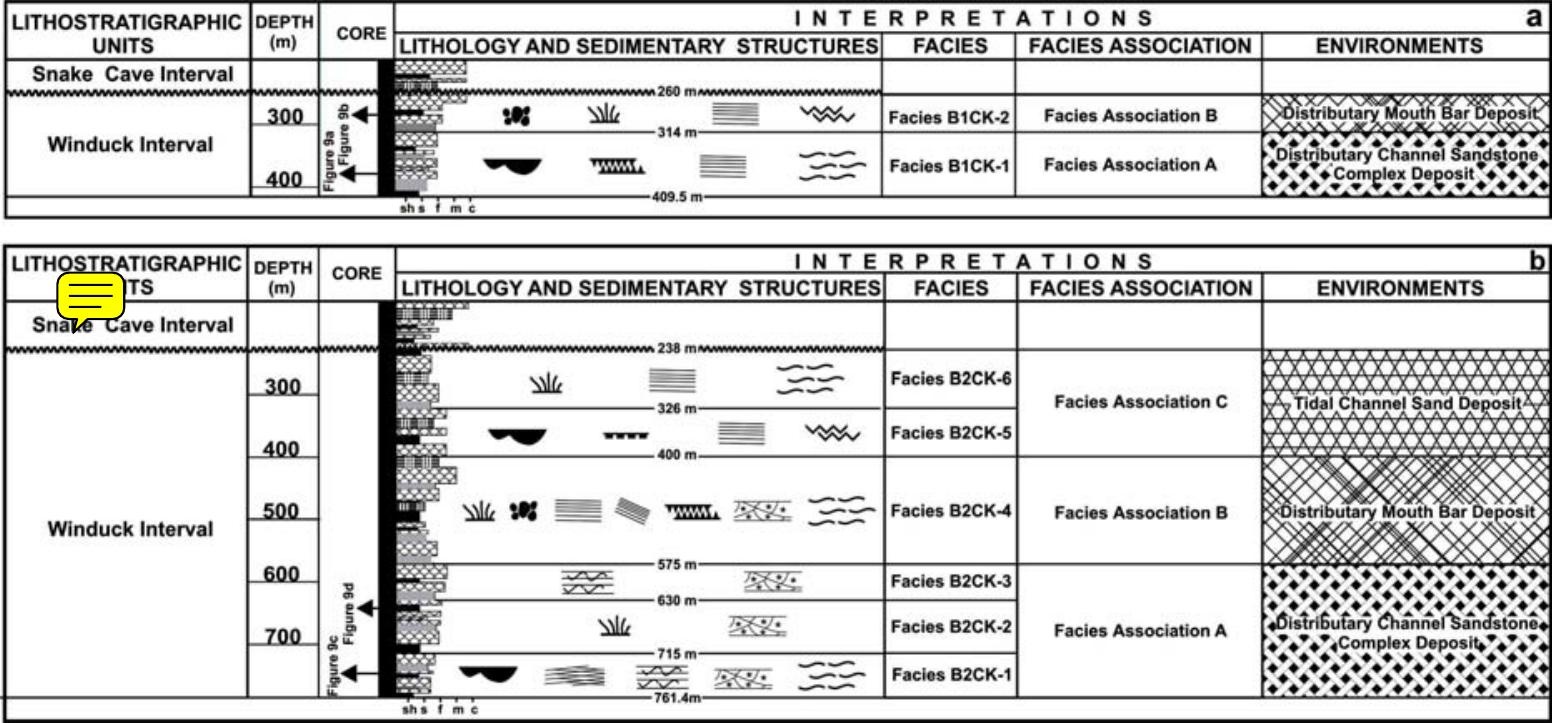

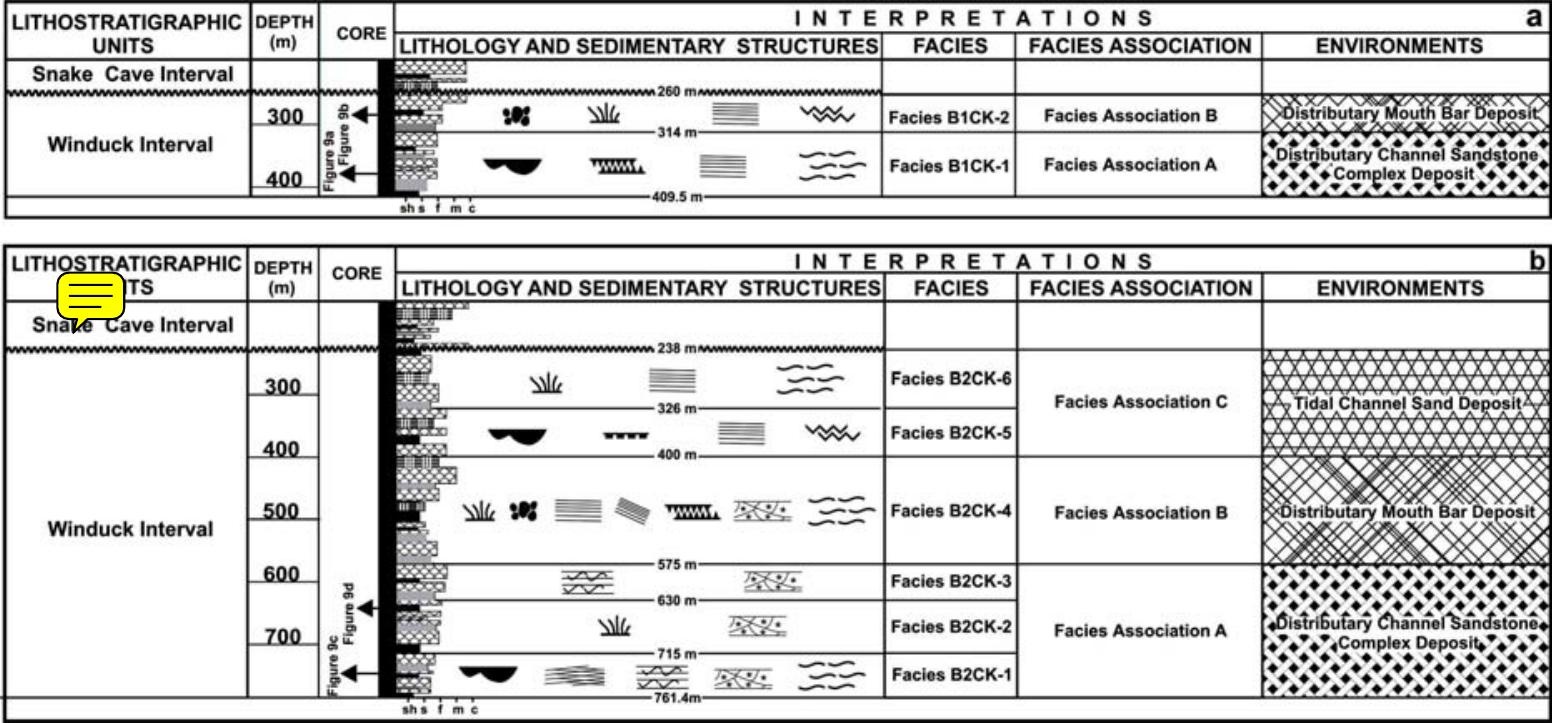

ENVIRONMENTS

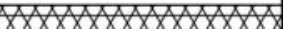

$7 \times \times \times \times \times \times 1$ Tidal Channel Sand Deposit NDNDNDNDD $\frac{1}{1}$

Distributary Mouth Bar Deposit $\times \times$

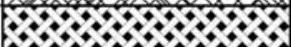

Distributary Channel'Sandstonê.

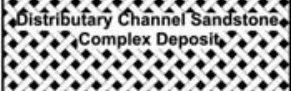

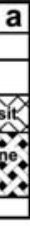




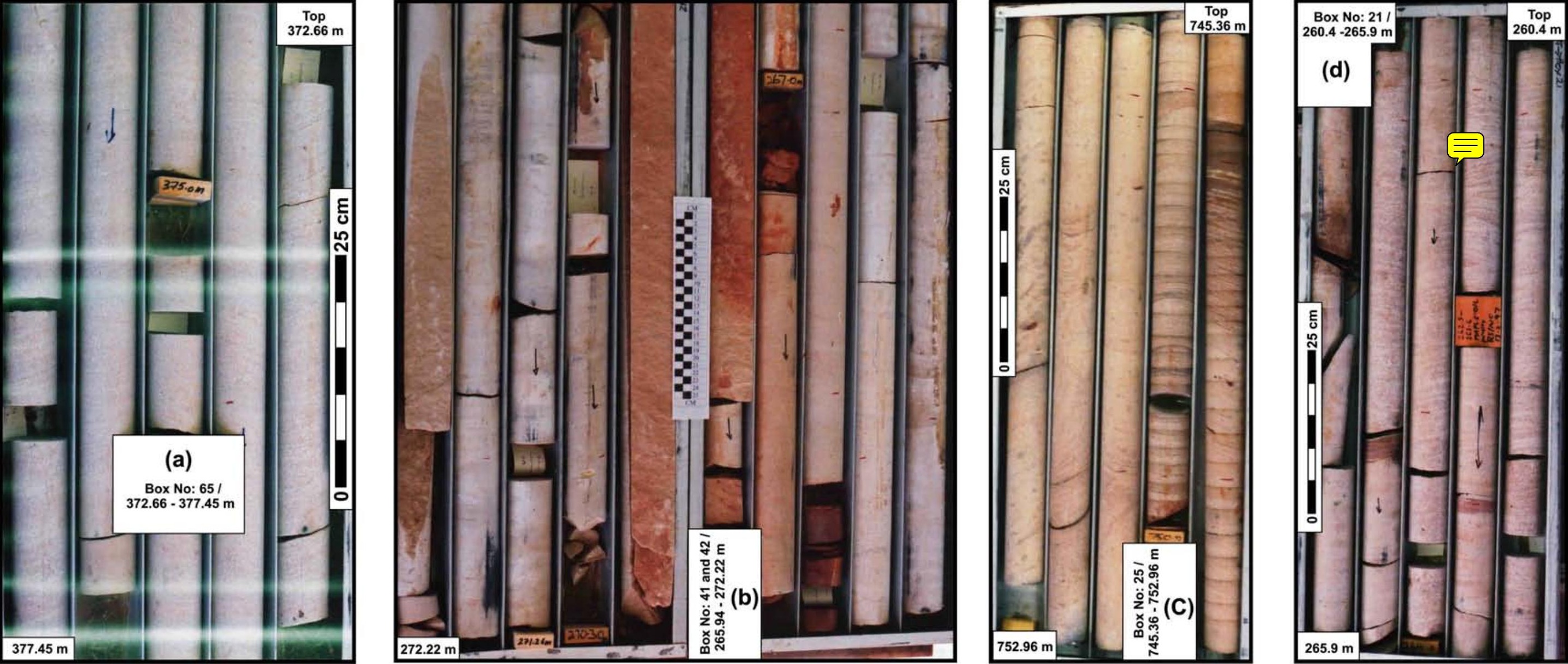




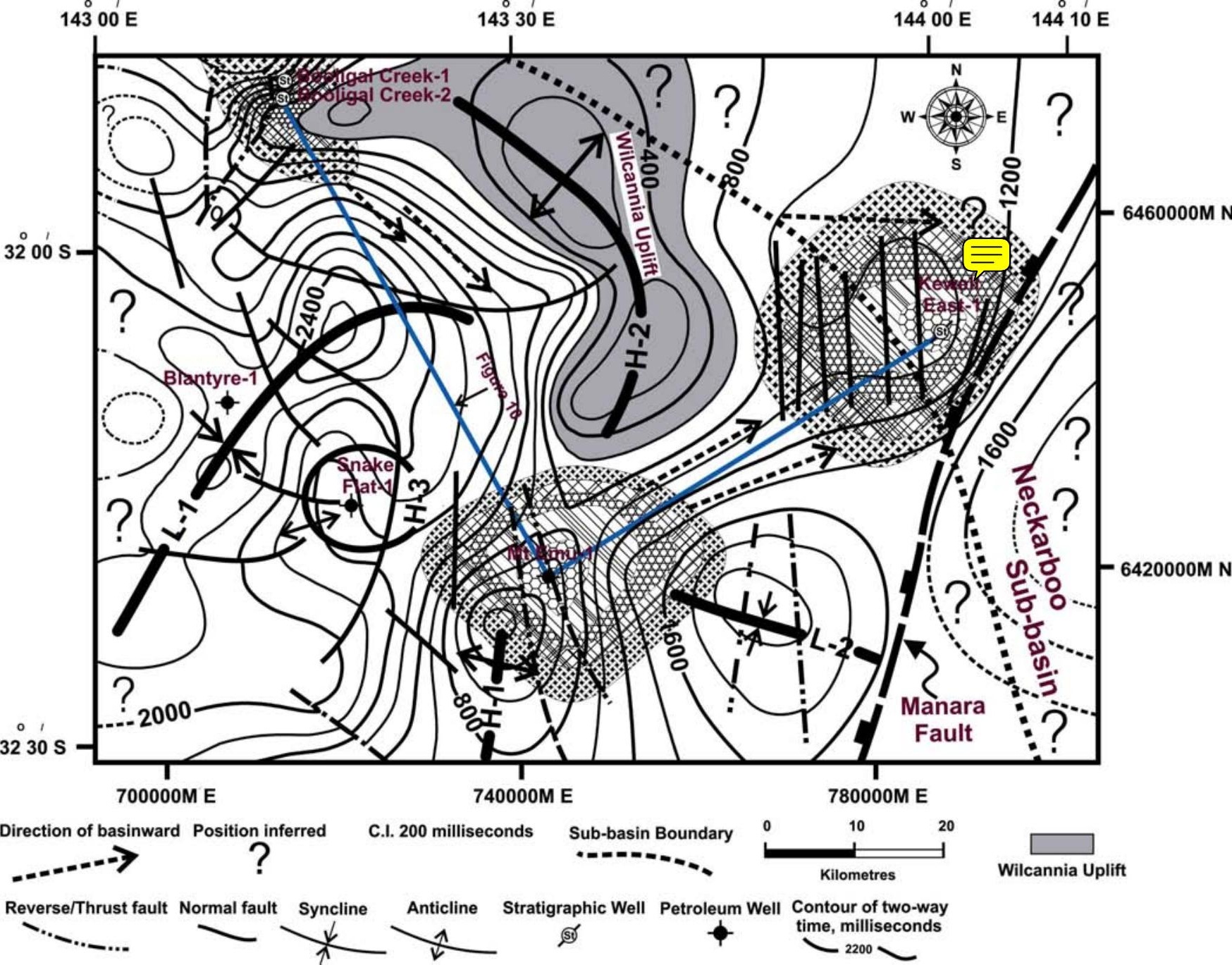

